
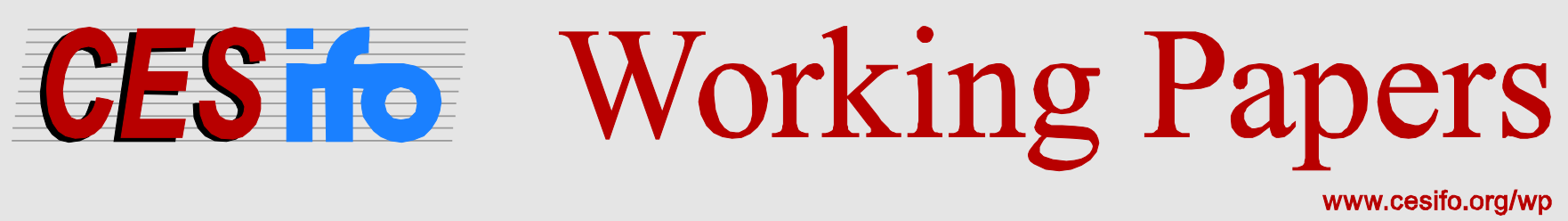

\title{
Budget Institutions and Government Effectiveness
}

\author{
Momi Dahan \\ Michel Strawczynski
}

CESIFO WORKING PAPER NO. 6219

CATEgory 2: Public CHOICE

NOVEMBER 2016

An electronic version of the paper may be downloaded

- from the SSRN website: Www.SSRN.com

- from the RePEc website: $\quad$ www.RePEc.org

- from the CESifo website: www.CESifo-group.org/wp 


\title{
Budget Institutions and Government Effectiveness
}

\begin{abstract}
Do budget institutions play a role in explaining why government effectiveness is higher in some advanced countries than in others? Employing an original panel dataset that spans four different years (1991, 2003, 2007 and 2012) we find that budget centralization has a negative and significant effect on government effectiveness in OECD countries after accounting for a list of control variables such as GDP per capita and government expenditure in addition to country and year fixed effects. We show that less centralized countries display significant better performance in health and infrastructure but similar effectiveness in tax collections. The negative impact of budget centralization seems to bite especially at the execution stage of the budgeting process, while it is not significant at the formulation and legislation stages. These results survive a list of sensitivity tests.
\end{abstract}

JEL-Codes: H110, H610.

Keywords: government effectiveness, budgeting process, bureaucratic autonomy.

\author{
Momi Dahan \\ School of Public Policy \\ The Hebrew University of Jerusalem \\ Jerusalem / Israel \\ momi.dahan@mail.huji.ac.il
}

\author{
Michel Strawczynski \\ School of Public Policy and Economics \\ Department, The Hebrew University of \\ Jerusalem / Israel \\ michel.strawczynski@mail.huji.ac.il
}

We thank Ariel Goldstein and Daniel Achdut for excellent research assistance. We benefited from comments by Sahar Alon-Barkat, Avi Ben-Bassat, Claude Berrebi, Sharon Gilad, Moshe Maor and participants in a seminar in the School of Public Policy at The Hebrew University of Jerusalem and IIPF 2016 conference in Lake Tahoe, USA . We also benefited from excellent remarks of three referees from the Journal. 


\section{Introduction}

This paper deals with the general question of why is government effectiveness higher in some countries than in others? The previous research has established that the quality of government is higher in rich, democratic, protestant and Common Law countries and in countries with a strong civilian tradition and homogeneous social structure. ${ }^{4}$ While these contributions promote our understanding of the cross country variation in quality of government, their policy implications are quite limited. The key determinants of the quality of government such as legal tradition or religion are not subject to policy makers' influence. In fact, we know relatively little on how to design effective public policy to improve the functioning of the state machinery despite its promising impact on the wellbeing of a country. ${ }^{5}$

Surprisingly, the literature on the determinants of government effectiveness has not explored the role of budgetary process. ${ }^{6}$ The rules that govern decision-making during the formulation, legislation and execution stages of the budget process are expected to play a significant role in determining the effectiveness of providing public services in various areas such as health or education. The delegation of power to the Finance Ministry/Prime Minister/President in the budgeting process (or budget centralization) may undermine the professional autonomy of the spending ministries that may hurt their ability to provide effective public services.

The concept of government effectiveness in this paper follows that of the World Bank (Kaufmann et al, 2010) that "captures perceptions of the quality of public services, the quality of the civil service and the degree of its independence from political pressures, the quality of policy formulation and implementation, and the credibility of the government's commitment to such policies." There is disagreement regarding the notion of government effectiveness and yet we prefer this definition for reasons that are discussed below.

\footnotetext{
${ }^{4}$ See for example, Putnam, 1993; La Porta et al., 1999; Serra, 2006; Triesman, 2007)

${ }^{5}$ On the effects of the quality of government on quality of life see for example North 1990, Rodrik 2004, Holmberg et al 2009 and Acemoglu and Robinson 2012.

${ }^{6}$ Andrews (2010) questioned the notion that better budget institutions are conducive to quality of government by presenting a lack of a consistent connection between the variation of a World Bank government effectiveness measure and various types of public financial management in a cross section of 38 countries (mainly OECD countries).
} 
The expected negative impact on government effectiveness may stem from the under-use of the professional knowledge in both the production function of public services and up to date public preferences. This is consistent with Fukuyama's (2013) hypothesis that a lower degree of autonomy reduces state capacity and therefore should negatively affect the quality of government. The knowledge advantage of professional staff in a certain line-ministry such as education reflects its shorter distance to the people (or "clients") when compared to the Finance Ministry. Note also that the negative effect of the degree of budget centralization on government effectiveness is expected to be more direct and instantaneous at the execution stage as compared to the formulation and legislative stages. One prominent example of budget procedures at execution that is directly linked to government effectiveness is the rule regarding the shift of unused funds between budgetary years. Banning on transfer of unused funds to the next year would incentivize spending ministries to overspend toward the end of the fiscal year even if the extra benefits that are associated with that spending are lower than the burden of the taxes that are needed to finance that spending. This type of behavior reflects the fear of a line ministry that unused funds would endanger its allocated long run budget size.

So far the literature on budget institutions has concentrated exclusively on the role of budget centralization for achieving a more responsible fiscal behavior. Von Hagen and Harden (1996) presented a model showing that indeed the delegation of power in the budgeting process to a non-spending ministry such as the Finance Ministry may solve the common pool problem that is necessary to attain an optimal size of provision of public goods. The empirical literature supports the theoretical prediction that lower degree of autonomy granted to spending ministries in budgeting process generated the expected benefits of reduced bias in central government expenditures, budget deficit and public debt (Von Hagen 1992, Poterba 1994, Alesina et al 1999, Hallerberg et al 2007 and 2009, de Haan et al 2013, Iara and Wolff 2014, Kelemen and Teo 2014). However, the potential costs of centralized budgetary process in terms of government effectiveness have been completely overlooked. One exception to this approach is Dahan and Strawczynski (2013), who show that while budget rules are effective in restraining government deficit and expenditure of OECD countries, they may damage government effectiveness in reducing inequality and poverty, due to their effect on the composition of 
public expenditure in favor of government wages and against government transfers to the poor, especially for countries that do not have a strong social constitution or solid social security laws.

In fact, the literature that explores the role of budgeting process on fiscal discipline uses frequently the words "fiscal performance" or even "effectiveness", but it is confined to the limited sense of fiscal discipline and ignores the general notion of government effectiveness. The book edited by Poterba and Von-Hagen (2008), which presents a collection of classic articles on the issue that was entitled Fiscal Institutions and Fiscal Performance, does not include even one article or a section on the performance of public services provision in terms of efficiency.

Unlike the unexplored role of autonomy at central governments, there is extensive research on the effect of power delegation to local government on effectiveness. According to the decentralization theorem, power delegation to sub-central governments can be beneficial because local governments are better informed about citizens preferences and due to interjurisdictional competition (Oates Brennan and Buchanan, 1980). Existing empirical evidence is mixed regarding the impact of fiscal decentralization on local government quality. See for example Fisman and Gatti (2002), Barankay and Lockwood (2007), Enikolopov and Zhuravskaya (2007), Fan et al (2009) and Kyriacou and Roca-Sagalés (2011) who show a positive impact of fiscal decentralization on government quality, Ben-Bassat el al (2015) for a negative effect and Treisman (2000) for mixed results depending on the employed measure of decentralization and level of GDP per capita.

The current study is the first attempt to explore the empirical relationship between the strategic power given to non-spending ministries (e.g., the Ministry of Finance) in the budgeting process and government effectiveness. Using panel data on 34 OECD countries, we find that reducing the degree of administrative autonomy that is represented by a more centralized budgetary process has a negative effect on state's administrative capacity as measured by the World Bank's index of government effectiveness. Understanding that relationship may advance our knowledge of how does the government 
"machine" works, which is a necessary step to specify the policy actions that are needed to upgrade the quality of government.

In the next section we present the conceptual framework that guides the empirical relations between budget institutions and government effectiveness. Section 3 presents the statistical model that we use to estimate the effects of budgeting process on government effectiveness. Section 4 describes the data and results and section 5 concludes.

\section{Conceptual Framework: budget institutions and government effectiveness}

The budgeting procedures and practices dictate the degree of autonomy of professional staff in spending ministries, such as education or health departments, and non-spending ministries, like the ministry of finance or the prime minister office. A more centralized budgeting process implies a lower autonomy in spending ministries together with strategic power in hands of non-spending ministries. The delegation of power in the budgeting process has important consequences on government effectiveness because it dictates the autonomy of the professional staff, and in particular that of its top officials, which is one of the key determinants of the quality of government (Fukuyama 2013). Thus, a higher level of budget centralization should affect negatively the managerial capacity of top executives in spending ministries but at the same time the professional staff in non-spending ministries enjoys a higher degree of power. While such a framework enhances budget responsibility, it is desirable to analyze the possible effects on government effectiveness.

The professional expertise on how to convert monetary means (budget) into desired government ends in certain fields, such as education or health, is expected to rest mainly in the spending ministries rather than in the finance ministry. Therefore, a more centralized budgeting process would lead to sub-optimal use of such knowledge. Abers and Keck (2009) demonstrate the importance of such mechanism in the context of decentralization of power from central government to local authorities and field activists. These authors show that activists are aware of details that escape the central government 
perception, which helps saving precious time that might be critical for the success of the policy reform. ${ }^{7}$ In addition, spending ministries have better and updated information on public preferences regarding certain government services due to its frequent encounters with their "clients". This type of knowledge is less likely to get the appropriate attention in more centralized decision-making environment (and lower autonomy). This negative effect on performance, however, may be attenuated to the extent that spending ministries tend to act in favor of special interests groups ("capture") instead of promoting the interests of the general public.

An additional channel that may affect government effectiveness is the link between the degree of discretion and the quality of top officials. In a more centralized process, highly skilled managers are expected to be attracted to serve at the finance ministry, while spending ministries are less attractive for top quality managers, who are motivated also by having an impact on public policy. In such environment the government is expected to show tighter fiscal discipline, but at the same time be less productive with regards to public services delivery.

Note that these three kinds of considerations (and especially the first two) are likely to undermine the effectiveness of the activity of spending ministries like Health or Education, unlike the degree of effectiveness in administrative divisions, like Tax Collection or Regulation Offices.

Let's summarize this discussion with two hypotheses:

H1: Government effectiveness is expected to be lower in countries with more centralized budgeting process after taking into account the degree of fiscal discipline.

H2: The negative effect of budget centralization on government effectiveness is likely to impact government outcomes under the responsibility of spending ministries such as health or education as opposed to activities under the responsibility of non-spending ministries such as tax collection.

\footnotetext{
${ }^{7}$ The positive effect of higher degree of autonomy is stressed also by Grindle (2004), who provides an extensive list of factors that are needed for effective policy aimed at reducing poverty.
} 
The degree of autonomy at the execution stage of the budgeting process in line-ministers has a direct and immediate impact on the effectiveness of spending ministries in providing public services provision. For example, spending ministries with minimal discretion to transfer money between budget line-items may prefer bad resource allocation in times of change. Such limited autonomy may induce strategic behavior due to the fear that the finance ministry would exploit its power to cut the line-budget when a request for a shift of money from unnecessary line item to other (more necessary one) is submitted. Additionally, the Finance Ministry may utilize such an opportunity to press the spending ministry to agree, for example, to a disputed structural change in return for agreeing to the requested reallocation of funds. ${ }^{8}$ As a result, officials in spending ministries might avoid shifting money between two budget line-items, which would have negative consequences on government effectiveness. The flexibility of transferring unused funds to the next year that may govern the behavior of spending ministries exemplifies as well the connection between budget centralization in the execution stage and government effectiveness. Strict rules on carry-over of funds may induce the wellknown behavior of spending spike in the last month of the fiscal year. Such a spike could not be consistent with efficient use of tax- payers' money, since part of this spending maybe driven by the strategic need of line ministries for preserving their budget size. Moreover, the lower flexibility of line ministries that is associated with more centralized process in the execution may hurt their ability to adjust public services provision according to society's demand in real time, which is particularly relevant in periods of reforms and changes in economic and technological conditions.

In contrast, the budgeting procedures in the formulation and legislation stages are less prone to affect directly, in the short-run, the effectiveness of supplying public goods. A balanced budget rule, which is a corner stone of the procedures in the budgeting preparation, is not expected to influence directly the effectiveness of providing education or health in the short term. Additionally, the period of time the parliament is allowed to deliberate the submitted budget, which is a standard item in almost every index of budget centralization (including ours), is less likely to determine government effectiveness in the

\footnotetext{
${ }^{8}$ Ben Bassat and Dahan (2006) suggest that this is a well-known practice in Israel.
} 
short run. Moreover, the degree of budget centralization in formulation and legislation stages, which affects fiscal discipline and drives a more responsible fiscal behavior, implies a positive impact on government effectiveness in the long run through its effect on spending priorities, uncertainty and inflation. Previous studies have established that budget centralization tend to improve fiscal discipline by lowering the level of public spending, budget deficit and public debt. We sum up these arguments with the following hypothesis:

H3: The negative effect of budget centralization on government effectiveness is expected to be more pronounced in the execution stage than in the formulation or legislation stages.

Interestingly, Gleich (2003) shows that while a higher degree of budget centralization is significant for reducing the budget deficit in the formulation and legislation stages, the delegation of power in the execution stage was not significant in reducing the budget deficit. This result stresses that while the rules that govern the implementation of the budget are important for the effectiveness of supplying public services, they seem less effective in achieving fiscal discipline. The opposite is true for the budgeting procedures in the formulation and legislation stages, that are essential tools to induce more responsible fiscal behavior, but do not have a direct and immediate effect on government effectiveness.

\section{The empirical relationship between autonomy and government effectiveness}

\subsection{The estimated model}

To test our hypotheses we exploit an original dataset on budget institutions and government effectiveness in four points in time for OECD countries. We estimate the 
effect of budget centralization on government effectiveness, employing the following statistical model:

(1) Government Effectiveness $i, t$

$$
\left.=a_{1} \text { (Budget Centralization) }\right)_{i, t-2}+\mathbf{X}_{i, t-2} \mathbf{b}+c_{t}+d_{i}+u_{i, t}
$$

where Government Effectiveness ${ }_{i, t}$ is the World Bank's measure of government effectiveness that is described below in country $i$ at the year $t$. Our central explanatory variable is measured by an index of budget centralization in country $i$ at the year $t-2$. In the next sub-section we explain how this index is constructed. We use a two years lag to account for the time that takes for a policy change to affect government effectiveness. $\mathbf{X}_{i, t-2}$ is a vector of time-varying country characteristics such as GDP per capita and Democracy with two years lag; $c_{t}$ is a fixed effect for each year in the sample, that is included in order to control for general trends; $d_{i}$ is a country fixed effect in order to control for idiosyncratic effects; $a$ and the vector $\mathbf{b}$ are unknown parameters to be estimated. Unobserved determinants of government effectiveness at the country level are represented by the error term, $u_{i t}$.

Due to data availability we restricted our empirical analysis to OECD countries. It helps to some extent to decrease the concern of omitted variables as a result of a more homogeneous institutional background. For obvious reasons, variables such as legal origins and religion composition and geographical location are excluded due to the inclusion of country fixed effects. ${ }^{9}$

\subsection{Data}

\section{$\underline{\text { Dependent variable/measuring government effectiveness }}$}

We use the World Bank's measure of perceived government effectiveness as our main dependent variable (Kaufmann, Kraay and Mastruzzi, 2010). The World Bank defines government effectiveness as follows: "government effectiveness captures perceptions of

\footnotetext{
${ }^{9}$ Their inclusion in a cross section regression did not affect our basic results.
} 
the quality of public services, the quality of the civil service and the degree of its independence from political pressures, the quality of policy formulation and implementation, and the credibility of the government's commitment to such policies." This measure intends to represent the effectiveness in a wide range of government activities such as primary education, healthcare and infrastructure. Government effectiveness is one of six indicators for the quality of governance that are measured by the World Bank (the other five indicators are Voice and Accountability, Political Stability and Absence of Violence, Regulatory Quality, Rule of Law and Control of Corruption). We choose this measure because it provides a broad picture of government effectiveness that none of the many alternative existing measures of quality of government covers. The World Bank's measure of government effectiveness is available from 1996 to 2014 for more than 200 countries, which allows us to employ also a panel analysis that is necessary to identify a more reliable effect of our key explanatory variable.

The World Bank's measure of government effectiveness is based on seven different sources for OECD countries data on government effectiveness (five sources from 1996 to 2006). ${ }^{10}$ For example, the World Economic Forum is one such source that provides effectiveness measures in the area of education and infrastructure. The original data is first coded between zero and one, and each ingredient gets a weight that increases with the correlation between different sources on the same content. The index of government effectiveness is normalized each year so that the global average equals 0 and the variance is one. The index ranges between -2.5 and 2.5 , where a higher value represents more effective government. It would be reasonable to expect small fluctuations from one year to another in government effectiveness in a particular country, and indeed the index of government effectiveness is quite stable over time. The rank of countries according to this measure fluctuates more as the period of time expands, but it captures both real changes in effectiveness and changes in the way this measure was constructed (Kaufmann, Kraay and Mastruzzi, 2010).

\footnotetext{
${ }^{10}$ The seven sources are Economist Intelligence Unit (Expert Assessment), World Economic Forum (Firm survey), The Gallup Organization (Households survey), French Ministry of the Economy, Industry and Employment (Expert Assessment), International Country Risk Guide (Expert assessments subject to peer review at the topic and regional levels), Global Insight (Expert Assessment) and Institute for Management Development in Lausanne, Switzerland (Business people survey).
} 
Switzerland and all Scandinavian countries have the highest score in OECD while the southern part of Europe and Mexico are at the bottom according to government effectiveness measures. Whereas the world average score in government effectiveness is by construction equal to zero, the average grade of the OECD countries is much higher and it reaches 1.3 in 2014. The average score of OECD countries is relatively stable over time, but the relative rank of a particular country may fluctuate quite significantly. For example, the governments in Japan and Korea are considerably more effective in 2014 than they were in 1996 while Italy and Spain show a substantial reduction in government effectiveness in that same period.

The difficulty to measure government outcomes, and especially to aggregate government output across various activities, opens the door for an array of ways to evaluate the quality of government or effectiveness. Indeed, there are quite a few measures of the quality of government that are published by various institutions and there is a live debate on the right way to measure government outcomes (Agnafors 2013, Fukuyama 2013, Rothstein 2014).

To explore the robustness of our findings, we consider also few additional indicators of government effectiveness in certain public activities, such as tax collection effectiveness (Consumption Tax Trends 2014, OECD), satisfaction with education system and infrastructure (taken from the World Economic Forum) and a computed measure of healthcare system efficiency (see below).

\section{$\underline{\text { Key explanatory variable }}$}

The degree of budget centralization is the key explanatory variable that captures one important aspect of bureaucratic autonomy. More centralized budgetary process, especially in the execution stage, reduces the degree of professional autonomy of lineministries. We constructed original measures of budget centralization in 34 OECD countries for the years 2003, 2007 and 2012 in the spirit of the literature on budget processes and commitment to fiscal discipline (See for example Von-Hagen and Harden, 1996). To expand our panel data we have added a measure of budget centralization that was computed by Hallerberg et al 2007 for European countries for the year 1991. Thus, 
our empirical analysis of budget centralization covers the years 1991, 2003, 2007 and 2012.

The index of budget centralization intends to represent the balance of power between spending and non-spending ministries in the preparation and execution budgeting stages, and between the executive and legislature institutions in the legislation stage. We use three surveys that were conducted by the OECD and the World Bank on budget practices in the years 2003, 2007 and 2012 (OECD/World Bank, 2003. 2007 and 2012). Each survey contains dozens of questions on the budget process in OECD countries. The answers are provided by the Central Budget Authority in each country and the OECD experts perform quality control of the responses in order to guarantee consistency and reliability. The three surveys are not completely comparable due to changes in the wording of questions and the introduction of extensive quality control of the responses. Moreover, a few questions that appear in the more recent survey were not included in the previous survey (and vice versa). To make our indices of budget centralization relatively comparable, we employ a battery of questions that most of them appear in all three surveys. To reduce further the risk of measurement error, due to potential changes in data collection procedures, the empirical analysis includes years fixed effects in the panel regressions.

The centralization measure in 2012 for the preparation stage is computed based on four features that are meant to capture the degree of autonomy of the line-ministries: fiscal rules, who has the authority to resolve budget dispute, whether government imposes budget ceilings on the initial spending requests of each line ministry, and the administrative location of the Central Budget Authority. Each of these four features is ranked between 0 (low centralization) and 10 (high centralization) and gets the same weight. The index is computed just for countries that have data on all four characteristics. We use the same procedure to compute the centralization measures at the preparation stage for the years 2003 and 2007. The questions in the OECD/World Bank survey are relatively similar in 2007 and 2012. There are two questions in the survey of 2003 that were not asked in the following two surveys, but nevertheless were used to construct the centralization measures at the preparation stage for 2003 (See Appendix Table 2). 
The centralization measure for the legislation stage consists of five characteristics: the maximum time span for deliberation, the consequences in case the budget is not approved by the parliament before the start of the fiscal year, the formal powers of the Legislature to amend the budget, the actual size of changes as a percentage of the proposed budget and the nature of the committee that deals with the budget (See Appendix Table 3). The questions that are used to compute the index are quite similar in all three surveys. To allow a summation across the three different stages, each of these five features is ranked between 0 (low centralization) and 10 (high centralization). The index of centralization at the approval stage is a simple average of these five characteristics.

The index of centralization at the execution stage comprises of five features: lump sum appropriations, the autonomy of line ministers to re-allocate funds within their own budget envelope, the autonomy of line ministers to borrow against future appropriations, the autonomy of line ministers to carry over unused funds or appropriations from one year to another and the total size of reserve funds. The questions that are employed to compute the index of centralization at the execution stage are relatively comparable in all three surveys of 2003, 2007 and 2012 (See Appendix Table 4). As before, each of these five features is ranked between 0 (low centralization) and 10 (high centralization), and the index of centralization at the execution stage is a simple average of these five characteristics.

In the empirical analysis we use a summary index of budget centralization by computing a simple average of the three indices of the budgetary process at different stages that were described above. Appendix Table 1 presents the summary index of budget centralization for OECD countries in the years 2003, 2007 and 2012 in addition to the year 1991.

The most remarkable feature that arises from Table 1 is that budget centralization remained very high for the whole period, both according to the summary index and to the execution stage index. While the first one ranges between 5.5 (in 2003) to 6.5 (in 2007), the index for the execution stage is even higher and ranges between 5.9 (in 2012) to 6.7 (in 2007). Note that the countries that have a value that is lower than the middle of the rank (5) are USA, Canada, Australia, Iceland and Mexico (Appendix Table 1). 
As can be expected, most countries keep their relative ranking over the years. The correlation between the index of budget centralization of 2012 and 2007 and between 2007 and 2003 are 0.54 and 0.68 , respectively (Appendix Table 1). The correlation is high, but not very high, due to the implemented changes in budgetary practices during this period of time. For example, many countries have introduced new fiscal rules during the covered period. ${ }^{11}$ As would be expected, our index of budget centralization for the year 2003 is highly correlated with a similar index that was computed by Hallerberg et al 2007 for European countries for the year 2004. ${ }^{12}$ Thus, it allows us to expand the covered period by adding to our dataset their index of budget centralization (delegation index) for the year $1991 .^{13}$

\section{Control variables}

To isolate the effect of our key explanatory variables of budget institutions we control for a list of variables that were found consistently in previous studies [see La-Porta et al (1999), Serra (2006), Triesman (2007), Bjørnskov (2011) and Ben-Bassat and Dahan (2015)] as correlated with quality of government, such as GDP per capita (taken from IMF World Economic Outlook Database, April 2015) and Democracy (from Freedom House). There are good theoretical and empirical reasons to include GDP per capita as one of the control variables. The theory of institutions suggests that higher economic development should increase the demand for more effective public institutions (e.g., North 1981, 1990 and Landes 1998) due to higher opportunity costs of inefficient government. ${ }^{14}$ We also include democracy that is considered an important factor for government performance because the separation of powers and freedom of the press endows key players with a mission to reveal government ineffectiveness and corruption Triesman (2007).

\footnotetext{
${ }^{11}$ OECD, 2014: Budgeting Practices and Procedures in OECD Countries, Table 2.9.

${ }^{12}$ The correlation reaches 0.62 . We find also a correlation of 0.8 between our index of centralization at the legislation and that of Wehner (2006) who has constructed a similar index for the year 2003. A correlation of 0.66 has been found between our index of centralization at the legislation and that of Kim (2015) for the year 2007.

${ }^{13}$ For comparability reasons, we have rescaled the original delegation index for 1991 to be between 0 and 10 to match the scale of our measures of budget centralization.

${ }^{14}$ However, one may also expect that government effectiveness affect GDP per capita. See also the dispute over the effect of economic growth on the World Bank's measure of the quality of governance (Kurtz and Schrank, 2007 and Kaufmann, Kraay and Mastruzzi, 2007b).
} 
We add to this list the ratio of public debt to GDP or the average size of budget surplus in percentages of GDP in the last decade (from OECD database), to account for the potential positive effect of fiscal discipline on government effectiveness. Thus, the coefficient of the index of budget centralization captures the marginal impact of autonomy on government effectiveness, after controlling for budget discipline. We also include government expenditure as a control variable: a higher government spending implies a higher challenge for government effectiveness.

\section{Results}

Before presenting the regressions' results it is worth looking at the partial relations between budget centralization index and government effectiveness across OECD countries in the year 2014. Figure 1 shows clearly that government effectiveness tends to be lower in countries with lower autonomy granted to spending ministries in the budgeting process.

Table 2 presents the panel results concerning the effect of budget institutions on government effectiveness. We first estimate the effect of our overall index of budget centralization on government effectiveness using the statistical model in Equation (1) with country and year fixed effects only (Table 2, column 1 ). ${ }^{15}$ As can be seen, the coefficient of budget centralization has the expected negative sign. The coefficient remains negative and significant also after controlling for the standard list of control variables (Table 2, columns 2-3). The OLS regressions' results imply that richer countries tend to have more effective government, as has been found in earlier literature but in cross-section empirical setting (La-porta 1999).

To isolate the effect of budget centralization, that is associated with less professional discretion by line ministries, we add debt to GDP ratio to the list of control variables which is intended to capture the degree of long-run budget discipline. In a different

\footnotetext{
${ }^{15}$ The standard errors are clustered at the country level. We use a two years lag except for the budget centralization index at the year 1991, where a lag of five years is employed, since government effectiveness measures are available only since 1996.
} 
regression this variable was substituted by the government surplus. Results show that the coefficients of these two variables are not significant. Thus, fiscal discipline has no additional impact on government effectiveness, as implied by the estimated coefficient whether it is measured by public debt or long-run budget surplus (defined as budget surplus in the preceding decade). The coefficient turns negative and borderline significant using public expenditure as a share of GDP instead of public debt or government surplus. Note that the coefficient of budget centralization means that for a given level of budget discipline higher budget centralization has a negative effect on government effectiveness which is in line with hypothesis 1 .

This finding implies that less autonomy, measured by budget centralization, undermines government effectiveness. The size of the estimated coefficient is relatively stable in the various specifications used in Table $2 .{ }^{16}$ Reducing the index of budget centralization by one standard deviation implies an increase of approximately $10 \%$ of the standard deviation of government effectiveness in OECD countries.

Tables 3-5 present the effect of budget centralization on government effectiveness in each and every stage of the budgetary process. Table 4 shows that the index of budgeting procedures at the execution stage has consistently a negative and significant impact on government effectiveness in all specifications. While the coefficients of the degree of budget centralization in the formulation and legislation stages have a negative sign, they are insignificant in all the estimated specifications (Tables 4-5). This different effect is consistent with hypothesis 2, which predicts that the formulation and the legislation stages are more important for fiscal discipline than the degree of autonomy at the execution phase, but they are less so for government effectiveness. In Table 6 we estimate the effect of three indices of budget centralization at all stages of budget indices of budget centralization simultaneously. This analysis shows that in some specifications there is a negative relationship between centralization at the legislation stage and government effectiveness but its significance disappear in our baseline regression. The outcomes of this estimation lend additional support to above conclusion, as it shows that

\footnotetext{
${ }^{16}$ The results regarding the effect of the summary index of budget centralization are quite similar when restricting our sample to countries with available data for all years covered in this research (i.e., balanced panel). The results do not appear in the tables but could be provided upon request.
} 
the effect of budget centralization at the execution stage on government performance remains negative and significant while the other two measures of budget centralization at the formulation and legislation stages are not significant.

In Table 7 we test the third hypothesis according to which the effect of budget centralization on government effectiveness should differ depending on the ministry in question. To execute this test, we employ four different indicators of government effectiveness in four particular public activities. The first indicator measures tax collection effectiveness (as computed in Consumption Tax Trends 2014, OECD), which is supposed to represent the finance ministry effectiveness. Unlike the measure of perceived government effectiveness that has been used throughout this study, tax collection effectiveness is based on actual data of tax revenues and statutory tax rates. The second indicator represents the government effectiveness in key spending ministry: healthcare system. We estimate the relative rank of a country in government efficiency in the healthcare system employing the standard stochastic frontier model as suggested by Greene (2005). We use two alternative panel estimation methodologies in the spirit of data envelopment analysis (DEA). In general, this estimation technics allow us to separate cross country variation in health outcomes such as life expectancy into heterogeneity and efficiency after controlling for public inputs like government spending on health. ${ }^{17}$ Note that these indicators are based on actual data, rather than assessment of experts, firms or households. The third and fourth indicators are taken from the Global Economic Forum that provides measures of perceived government effectiveness in education and infrastructure. These two indicators exemplify the government effectiveness in additional two key spending ministries.

The results in Table 7 confirm the third hypothesis, but they are restricted to the execution stage. Each cell in Table 7 shows a budget centralization coefficient estimated in a regression that includes Log GDP per-capita, Democracy index and country and year fixed effect. While the impact of budget centralization on government effectiveness in health, infrastructure and education is negative and mostly significant, we do find positive

\footnotetext{
${ }^{17}$ In the first stage of the estimation we use a parsimonious version with two inputs: public spending on health (the data on life expectancy and public spending are taken from OECD health database) and population density (taken from the World Bank database).
} 
but insignificant effect on tax collection effectiveness, which is under the responsibility of the finance ministry.

Table 8 presents a sensitivity analysis of our results using additional set of control variables. The focus so far has been on what Hallerberg et al (2009) have defined as the delegation approach to budgetary institutions. To explore the role of the contract approach, which consists of establishing rules that reduce the discretion of spending ministers without granting extra powers to the finance ministers, we constructed a Fiscal Rules Index using the methodology proposed by Debrun et al (2008). ${ }^{18}$ The Index was constructed using various kinds of rules like deficit, expenditure and income rules at the national and supra-national level. Their strength's features such as formal enforcement procedure, coverage, legal basis, well-specified escape clauses and supporting procedures/institutions (taken from IMF database) receive a score between one and ten. Following Debrun et al (2008), the most effective rules get the highest weight (one) and all others get 0.5 . In practice, the fiscal rules index ranges between 0 and 274 . Including a measure of fiscal rules as a control variable is important since it might be correlated with both the dependent variable and the main explanatory variable. Column (1) in table 8 shows that the coefficient of our main explaining variable - budget centralization remains negative and significant while the fiscal rules index has a positive and significant coefficient.

Second, we control for political regional decentralization, using a new index that was built by Hooghe et al. (2010). This index takes into account the regional political authority, which is usually decentralized in federal countries, while the opposite is true for unitary countries: USA and Canada have a relatively high figure, and Israel and Slovenia have low figures. Consistently with findings in the literature, column (2) demonstrates that political decentralization is positively correlated with government effectiveness, and the coefficient is significant at 1 percent. More importantly, our main result remains the same as the negative effect of budget centralization is significant and becomes even higher.

18 There are several papers that have empirically studied the contract approach, which consists of establishing rules that reduce the influence of spending ministers without giving extra powers to the finance ministers. For a review of the literature see Eslava (2011). 
Our central finding continues to survive the inclusion of two additional control variables: election years (taken from Norsk Center) and log of population size (taken from OECD). The results in Table 8 implies that government effectiveness is not sensitive to election year but it is affected (borderline significant) by the size of population. It might reflect the difficulty of coping with higher challenge of governments for serving larger populations.

In Table 8 we also explore the robustness of the main result to a split of our sample by the level of GDP per capita. Looking at Figure 1 one may suggest two opposite links between government performance and budget institutions: a negative correlation between government effectiveness and budget centralization for rich OECD countries, and a positive one for poor OECD countries. To explore this hypothesis, in regressions (5) and (6) we estimate the effect of budget centralization on government effectiveness after dividing the sample into two groups: countries with a GDP per-capita above and below the median. As expected the reduced number of observations leads to less precision in estimating the effect of budget centralization in each of the two groups. The results show that the correlation between centralization and government effectiveness remains negative for both groups of countries but it is significant for low GDP per-capita countries only.

Concerning the potential reverse causality, it is unclear whether poor government effectiveness drives policymakers to shape more or less centralized budgetary process. It depends on their beliefs regarding the true link between budget centralization and government effectiveness. As discussed in section 2, one may speculate that improving fiscal discipline by granting more power to finance ministry (i.e. more centralized budgeting process) is the right way to combat meager government performance but a competing story that it is equally convincing would be that giving more authority to spending ministries (i.e. less centralization) may advance government effectiveness as well. In Table 9 we present a test of reverse causality by employing the most recent change in the index of budget centralization (between the last two years for which the data is available) as a dependent variable and the preceding change in government effectiveness as an independent variable. The estimated coefficient suggests that past 
performance in terms of government effectiveness does not predict future change in the degree of budget centralization, reducing our suspicion for reverse causality.

\section{Summary and Conclusions}

By using an indicator of government effectiveness, this study reveals that bureaucratic autonomy plays a positive role in explaining the variation in government effectiveness for OECD countries. Employing an original data set on budget centralization for particular years between 1991 and 2012 (1991, 2003, 2007 and 2012) we show that governments in OECD countries that are characterized by less centralized budgetary process, which implies more autonomy to spending ministries, present better performance as measured by the World Bank's indicator of government effectiveness.

The effect of budgetary procedures and practices on government effectiveness in OECD countries is estimated after accounting for country and years fixed effects, as well as a standard list of control variables. This list includes the level of economic development (GDP per capita), the strength of democracy and measures of fiscal discipline. Moreover, these results survive an additional list of sensitivity tests.

In addition, we find that less centralized countries display significant better performance in health and infrastructure but similar effectiveness in tax collections. This is in line with the hypothesis that providing spending ministries with more power in the budgetary process helps to take advantage of their professional knowledge both in terms of better resources allocation and superior fit of public spending to public preferences. The empirical analysis also lends support to the hypothesis that budget centralization seems to bite especially at the execution stage of the budgeting process.

This study uncovers the neglected tradeoff that policymakers face between fiscal discipline and government effectiveness in crafting the rules that govern the budgetary process. According to our findings, designing institutions that aim at achieving fiscal discipline (e.g., reduced budget deficits), as suggested in the literature on budget procedures (Von Hagen and Harden 1996), may come at the expense of lower government effectiveness. Nevertheless, in light of the result regarding the lack of effect of budget centralization at the execution stage on fiscal discipline (Gleich 2003), our 
findings suggest that policy makers may reduce the degree of budget centralization at the execution stage without paying the cost of diminished fiscal discipline. While the findings of this study constitute a first attempt to shed light on the complex relationship between bureaucracy autonomy and government effectiveness, it may advance our knowledge on how should the state administrative machinery be designed, which is an important feature for the well-being of people in developed countries.

\section{References}

Abers, Rebecca Neaera, and Margaret E. Keck. (2009). "Mobilizing the state: The erratic partner in Brazil's participatory water policy." Politics \& Society 37.2: 289-314.

Acemoglu, Daron, James A. Robinson. (2012). Why nations fail: the origins of power, prosperity and poverty. Vol. 4. New York: Crown Business.

Agnafors, Marcus. (2013). "Quality of Government: Toward a More Complex Definition." American Political Science Review 107.03: 433-445.

Alesina, Alberto, Ricardo Hausmann, Rudolf Hommes, and Ernesto Stein. (1999). "Budget institutions and fiscal performance in Latin America." Journal of development Economics 59, no. 2: 253-273.

Andrews, Matt. (2010). "Good government means different things in different countries." Governance 23.1: 7-35.

Barankay, Iwan, and Ben Lockwood. (2007). "Decentralization and the productive efficiency of government: Evidence from Swiss cantons." Journal of public economics 91.5: 1197-1218.

Ben-Bassat, Avi, and Momi Dahan. (2006). "The Balance of Power in the Budgeting Process." The Israeli Democracy Institute.

Ben Bassat Avi and Momi Dahan. (2015). "The Regulation of Political Finance and Corruption" forthcoming in Election Law Journal.

Ben-Bassat, Avi., Momi Dahan and Esteban F. Klor. (2015). "Is Centralization a Solution to the Soft Budget Constraint Problem?", CEPR Discussion Paper No. DP10789.

Brennan, Geoffrey, and James M. Buchanan. The power to tax: Analytic foundations of a fiscal constitution. Cambridge University Press, 1980.

Bjørnskov, Christian. (2011). "Combating corruption: On the interplay between institutional quality and social trust." Journal of Law and Economics 54.1: 135-159. 
Dahan, Momi, and Michel Strawczynski. (2013). "Fiscal rules and composition bias in OECD countries." Journal of Policy Analysis and Management 32.3: 484-504.

De Haan, Jakob, Richard Jong-A-Pin, and Jochen O. Mierau. (2013). "Do budgetary institutions mitigate the common pool problem? New empirical evidence for the EU." Public Choice 156.3-4: 423-441.

Debrun, Xavier, Laurent Moulin, Alessandro Turrini, Joaquim Ayuso-i-Casals and Manmohan S. Kumar (2008), "National fiscal rules", Economic Policy, 297-362.

Enikolopov, Ruben, and Ekaterina Zhuravskaya. (2007). "Decentralization and political institutions." Journal of Public Economics 91, no. 11: 2261-2290.

Eslava, M. (2011). "The Political Economy of Fiscal Deficits: A Survey", Journal of Economic Surveys, 25 (4): 645-673.

Fan, C. Simon, Chen Lin, and Daniel Treisman. (2009). "Political decentralization and corruption: Evidence from around the world." Journal of Public Economics 93.1: 14-34.

Fisman, Raymond, and Roberta Gatti. (2002). "Decentralization and corruption: evidence across countries." Journal of Public Economics 83.3: 325-345.

Freedom House. (2015). Freedom in the World 2015 (Washington, DC: Freedom House).

Fukuyama, Francis. (2013) "What is governance?" Governance 26.3: 347-368.

Gleich, Holger. (2003). "Budget institutions and fiscal performance in Central and Eastern European countries", European Central Bank Working Paper, No 215.

Greene, William. (2005). "Reconsidering heterogeneity in panel data estimators of the stochastic frontier model." Journal of Econometrics 126.2: 269-303.

Grindle, Merilee S. (2004). "Good Enough Governance: Poverty Reduction and Reform in Developing Countries", Governance 17.4: 525-548.

Hallerberg, Mark, Rolf Strauch, and Jürgen Von Hagen. (2007). "The design of fiscal rules and forms of governance in European Union countries." European Journal of Political Economy 23, no. 2: 338-359.

Hallerberg, Mark, Rolf Rainer Strauch, and Jürgen Von Hagen. (2009). Fiscal governance in Europe. Cambridge University Press.

Holmberg, Sören, Bo Rothstein, and Naghmeh Nasiritousi. (2009). "Quality of government: What you get." Annual Review of Political Science 12: 135-161.

Hooghe, Liesbet, Gary Marks, and Arjan H. Schakel (2008), "Measuring Regional Authority", Regional and Federal Studies, vol. 8, 111-121. 
Iara, Anna, and Guntram B. Wolff. (2014). "Rules and risk in the euro area." European Journal of Political Economy 34: 222-236.

International Monetary Fund, World Economic Outlook Database, April 2015

Kaufmann, Daniel, Aart Kraay, and Massimo Mastruzzi. (2004). "Governance matters III: Governance indicators for 1996, 1998, 2000, and 2002." The World Bank Economic Review 18.2: 253-287.

Kaufmann, Daniel, Aart Kraay, and Massimo Mastruzzi. (2007a). "Worldwide governance indicators project: Answering the critics." World Bank Policy Research Working Paper 4149.

Kaufmann, Daniel, Aart Kraay, and Massimo Mastruzzi. (2007b). "Growth and governance: A reply." Journal of Politics 69.2: 555-562.

Kaufmann, Daniel, Aart Kraay and Massimo Mastruzzi. (2010). "The Worldwide Governance Indicators: Methodology and Analytical Issues". World Bank Policy $\begin{array}{llll}\text { Research } & \text { Working } & \text { Paper } & \text { No. }\end{array}$ (http://papers.ssrn.com/sol3/papers.cfm?abstract_id=1682130).

Kelemen, R. Daniel, and Terence K. Teo. (2014). "Law, focal points, and fiscal discipline in the United States and the European Union." American Political Science Review 108.02: 355-370.

Kim, Chunsoon. (2015). "A study on compilation and improvement of indices for legislative budgetary institutions: With focus on comparative analysis of current institutions in 60 countries", OECD Journal on Budgeting, Vol. 14/3.

Kurtz, Marcus J., and Andrew Schrank. (2007). "Growth and governance: Models, measures, and mechanisms." Journal of politics 69.2: 538-554.

Kyriacou, Andreas, and Oriol Roca-Sagalés. (2011). "Fiscal and political decentralization and government quality." Environment and Planning C: Government and Policy 29, no. 2: $204-223$.

La Porta, R., Lopez-de-Silanes, F., Shleifer, A., \& Vishny, R. (1999). "The Quality of Government", Journal of Law, Economics, and organization, 15(1), 222-279.

Landes, David. (1998). The Wealth and Poverty of Nations, New York: W. W. Norton.

North, Douglass. (1981). Growth and structural change, New York: W. W. Norton.

North, Douglass. (1990). Institutions, Institutional change and Economic Performance, Cambridge: Cambridge University Press.

Oates, Wallace E. (1972). Fiscal Federalism, New York: Harcourt. 
OECD/World Bank Budgeting Practices and Procedures Survey, 2003

OECD Budgeting Practices and Procedures Survey, 2007

OECD International Database of Budgeting Practices and Procedures Survey, 2012 www.oecd.org/gov/budget/database

OECD. (2014). Budgeting Practices and Procedures in OECD Countries, Table 2.9

OECD. (2014). Consumption Tax Trends 2014: VAT/GST and excise rates, trends and policy issues, OECD Publishing, Paris. DOI: http://dx.doi.org/10.1787/ctt-2014-en

OECD. (2015). General government deficit (indicator). doi: 10.1787/77079edb-en (Accessed on 13 December 2015)

OECD, Economic Outlook 98 database, 2015.

OECD, Health Statistics 2015. October 2015.

Poterba, J. (1994). State responses to fiscal crises: The effects of budgetary institutions and politics. Journal of Political Economy, 102, 799-821.

Poterba, James M., and Jurgen von Hagen, eds. (2008). Fiscal institutions and fiscal performance. University of Chicago Press.

Putnam, Robert D. (1993) Making democracy work: Civic traditions in modern Italy. Princeton university press.

Rodrik, Dani, Arvind Subramanian, and Francesco Trebbi. (2004). "Institutions rule: the primacy of institutions over geography and integration in economic development." Journal of economic growth 9.2: 131-165.

Rothstein Bo. (2014). "Human well-being and the lost relevance of political science.".

Serra, Danila. (2006). "Empirical determinants of corruption: A sensitivity analysis." Public Choice 126.1-2: 225-256.

Treisman, Daniel. (2000) "Decentralization and the Quality of Government." Manuscript UCLA.

Treisman, Daniel. (2007). "What have we learned about the causes of corruption from ten years of cross-national empirical research?" Annual Review of Political Science 10: 211244.

Von Hagen, Jurgen. (1992). "Budgeting procedures and fiscal performance in the European Communities." Economic papers 96: 1-79.

Von Hagen, Jurgen and Ian Harden. (1996). " Budget processes and commitment to fiscal discipline", European Economic Review 39 (3-4), 771-779. 
World Economic Forum, The global competitiveness index historical dataset, 2005-2015.

Wehner, Joachim. (2006). "Assessing the power of the purse: An index of legislative budget institutions." Political studies 54.4: 767-785.

World Bank, World Development Indicators database, 2015. 
Table 1: Descriptive statistics

\begin{tabular}{|c|c|c|c|c|c|}
\hline Variable & 1996 & 2005 & 2009 & 2014 & Overall \\
\hline \multicolumn{6}{|l|}{ WB Government effectiveness } \\
\hline Mean & 1.348 & 1.373 & 1.330 & 1.315 & 1.341 \\
\hline Standard deviation & $(0.611)$ & $(0.564)$ & $(0.545)$ & $(0.522)$ & $(0.556)$ \\
\hline Between & & & & & 0.542 \\
\hline Within & & & & & 0.146 \\
\hline No of observation & 34 & 34 & 34 & 34 & 136 \\
\hline \multicolumn{6}{|l|}{ Budget Centralization (BC) } \\
\hline Mean & 4.540 & 5.470 & 6.500 & 6.284 & 5.904 \\
\hline Standard deviation & $(1.969)$ & $(1.389)$ & $(1.088)$ & $(1.094)$ & $(1.463)$ \\
\hline Between & & & & & 0.930 \\
\hline Within & & & & & 1.177 \\
\hline No of observation & 15 & 28 & 33 & 34 & 110 \\
\hline \multicolumn{6}{|l|}{ BC at the Formulation stage } \\
\hline Mean & 4.985 & 4.225 & 6.989 & 7.151 & 6.131 \\
\hline Standard deviation & $(3.015)$ & $(1.760)$ & $(1.871)$ & $(1.722)$ & $(2.340)$ \\
\hline Between & & & & & 1.573 \\
\hline Within & & & & & 1.793 \\
\hline No of observation & 15 & 24 & 33 & 34 & 106 \\
\hline \multicolumn{6}{|l|}{$\underline{B C \text { at the Legislation stage }}$} \\
\hline Mean & 4.100 & 5.825 & 5.756 & 5.441 & 5.427 \\
\hline Standard deviation & $(2.687)$ & $(1.755)$ & $(1.094)$ & $(1.349)$ & $(1.747)$ \\
\hline Between & & & & & 1.077 \\
\hline Within & & & & & 1.409 \\
\hline No of observation & 15 & 26 & 28 & 28 & 97 \\
\hline \multicolumn{6}{|l|}{ BC at the Execution stage } \\
\hline Mean & 4.626 & 6.198 & 6.702 & 5.946 & 6.035 \\
\hline Standard deviation & $(2.210)$ & $(1.555)$ & $(1.470)$ & $(1.072)$ & $(1.652)$ \\
\hline Between & & & & & 1.107 \\
\hline Within & & & & & 1.260 \\
\hline No of observation & 15 & 22 & 30 & 28 & 95 \\
\hline
\end{tabular}

Note: All explanatory variables are computed for the years 2012, 2007, 2003 and 1991 and all dependent variables are calculated for the years 2014, 2009, 2005 and 1996 
Table 1: Descriptive statistics - cont.

\begin{tabular}{|c|c|c|c|c|}
\hline Variable & 1991 & 2003 & 2007 & 2012 \\
\hline Tax collection effectiveness & $\begin{array}{c}0.544 \\
(0.135) \\
31\end{array}$ & $\begin{array}{c}0.586 \\
(0.140) \\
33\end{array}$ & $\begin{array}{c}0.545 \\
(0.155) \\
33\end{array}$ & $\begin{array}{c}0.552 \\
(0.164) \\
33\end{array}$ \\
\hline $\begin{array}{l}\text { Health Technical Efficiency-ML } \\
\text { random effects model (Battese-Coelli 1995) }\end{array}$ & $\begin{array}{c}0.989 \\
0.005 \\
31\end{array}$ & $\begin{array}{c}0.991 \\
0.003 \\
34\end{array}$ & $\begin{array}{c}0.992 \\
0.002 \\
34\end{array}$ & $\begin{array}{c}0.993 \\
0.002 \\
33\end{array}$ \\
\hline $\begin{array}{l}\text { Health Technical Efficiency - True } \\
\text { fixed-effects model (Greene, 2005) }\end{array}$ & $\begin{array}{c}0.975 \\
(0.006) \\
31\end{array}$ & $\begin{array}{c}0.933 \\
(0.043) \\
34\end{array}$ & $\begin{array}{c}0.906 \\
(0.059) \\
34\end{array}$ & $\begin{array}{c}0.901 \\
(0.070) \\
33\end{array}$ \\
\hline Quality of primary education & $\begin{array}{l}-- \\
-- \\
--\end{array}$ & $\begin{array}{c}4.880 \\
(0.883) \\
34\end{array}$ & $\begin{array}{c}4.797 \\
(0.996) \\
34\end{array}$ & $\begin{array}{c}4.852 \\
(0.844) \\
34\end{array}$ \\
\hline Quality of overall infrastructure & $\begin{array}{l}-- \\
-- \\
--\end{array}$ & $\begin{array}{c}5.263 \\
(0.998) \\
34\end{array}$ & $\begin{array}{c}5.294 \\
(1.004) \\
34\end{array}$ & $\begin{array}{c}5.405 \\
(0.693) \\
34\end{array}$ \\
\hline Log GDP per-capita & $\begin{array}{c}9.713 \\
(0.458) \\
30\end{array}$ & $\begin{array}{c}10.161 \\
(0.423) \\
34\end{array}$ & $\begin{array}{c}10.409 \\
(0.384) \\
34\end{array}$ & $\begin{array}{c}10.473 \\
(0.356) \\
34\end{array}$ \\
\hline Democracy (from 1 to 7 ) & $\begin{array}{c}6.500 \\
0.741 \\
32\end{array}$ & $\begin{array}{c}6.735 \\
0.511 \\
34\end{array}$ & $\begin{array}{c}6.838 \\
0.439 \\
34\end{array}$ & $\begin{array}{c}6.765 \\
0.567 \\
34\end{array}$ \\
\hline General government debt ( $\%$ GDP) & $\begin{array}{c}52.4 \\
28.7 \\
20\end{array}$ & $\begin{array}{c}52.4 \\
32.7 \\
34\end{array}$ & $\begin{array}{c}48.5 \\
34.9 \\
34\end{array}$ & $\begin{array}{c}71 \\
45.8 \\
34\end{array}$ \\
\hline Government Expenditures (\% GDP) & $\begin{array}{c}44.405 \\
(11.396) \\
22\end{array}$ & $\begin{array}{c}41.453 \\
(8.749) \\
34\end{array}$ & $\begin{array}{c}39.337 \\
(8.083) \\
34\end{array}$ & $\begin{array}{c}43.140 \\
(8.783) \\
34\end{array}$ \\
\hline Fiscal Rules (from 0 to 10 ) & $\begin{array}{c}0.346 \\
0.888 \\
32\end{array}$ & $\begin{array}{c}2.949 \\
2.146 \\
32\end{array}$ & $\begin{array}{c}3.664 \\
1.912 \\
32\end{array}$ & $\begin{array}{c}4.67 \\
2.421 \\
32\end{array}$ \\
\hline Political Decentralization (from 1 to 12 ) & $\begin{array}{c}10.915 \\
8.964 \\
25\end{array}$ & $\begin{array}{c}10.890 \\
8.343 \\
28\end{array}$ & $\begin{array}{c}11.224 \\
8.112 \\
28\end{array}$ & $\begin{array}{c}11.296 \\
8.250 \\
28\end{array}$ \\
\hline Log Population Size & $\begin{array}{c}16.314 \\
1.547 \\
34\end{array}$ & $\begin{array}{c}16.389 \\
1.553 \\
34\end{array}$ & $\begin{array}{c}16.41 \\
1.549 \\
34\end{array}$ & $\begin{array}{c}16.45 \\
1.547 \\
34\end{array}$ \\
\hline
\end{tabular}

Note: The first figure is the variable average, the standard deviation is in parentheses and the number of observations is in the third row. All explanatory variables are calculated for the years 2012, 2007, 2003 and 1991. All dependent variables are computed for the years 2014, 2009, 2005 and 1996 apart from Quality of primary education/overall infrastructure for which the first period refers to the years 2007/2006 respectively and the two Health Technical Efficiency variables and Tax collection effectiveness for which the fourth period refers to the years 2013 and 2012 , respectively. Both Health Technical Efficiency variables for Chile in the first period refer to the year 1997 while data for Australia, Ireland and Luxembourg in the fourth period refers to the year 2012 due to data constraints. 
Table 2: Budget institutions and government effectiveness - all three stages

\begin{tabular}{|c|c|c|c|c|c|c|}
\hline & \multicolumn{6}{|c|}{ The dependent variable: WB government effectiveness } \\
\hline & $(1)$ & $(2)$ & $(3)$ & (4) & $(5)$ & $(6)$ \\
\hline $\begin{array}{l}\text { Budget Centralization } \\
\text { Summary index }\end{array}$ & $\begin{array}{c}-\mathbf{- 0 . 0 3 0} * * \\
(0.014)\end{array}$ & $\begin{array}{c}-\mathbf{- 0 . 0 3 3 * *} \\
(0.013)\end{array}$ & $\begin{array}{c}-\mathbf{- 0 . 0 3 3} * * \\
(0.014)\end{array}$ & $\begin{array}{l}\mathbf{- 0 . 0 2 6 *} \\
(0.014)\end{array}$ & $\begin{array}{l}\mathbf{- 0 . 0 3 1 *} \\
(0.016)\end{array}$ & $\begin{array}{l}\mathbf{- 0 . 0 3 6 * *} \\
(0.015)\end{array}$ \\
\hline Log GDP per-capita & & $\begin{array}{c}\mathbf{0 . 5 0 0 * *} \\
(0.203)\end{array}$ & $\begin{array}{c}\mathbf{0 . 4 8 6 * *} \\
(0.225)\end{array}$ & $\begin{array}{r}\mathbf{0 . 9 5 2} * * \\
(0.381)\end{array}$ & $\begin{array}{l}\mathbf{0 . 8 4 4} * * \\
(0.316)\end{array}$ & $\begin{array}{r}\mathbf{0 . 6 2 0 * *} \\
(0.274)\end{array}$ \\
\hline Democracy & & & $\begin{array}{c}0.020 \\
(0.081)\end{array}$ & $\begin{array}{l}-0.037 \\
(0.089)\end{array}$ & $\begin{array}{l}-0.045 \\
(0.086)\end{array}$ & $\begin{array}{l}-0.032 \\
(0.077)\end{array}$ \\
\hline General government debt & & & & $\begin{array}{c}0.001 \\
(0.001)\end{array}$ & & \\
\hline Government Surplus & & & & & $\begin{array}{l}-0.004 \\
(0.011)\end{array}$ & \\
\hline Government expenditures & & & & & & $\begin{array}{l}-\mathbf{0 . 0 0 9 *} \\
(0.005)\end{array}$ \\
\hline Adj.R ${ }^{2}$ & 0.219 & 0.268 & 0.261 & 0.293 & 0.262 & 0.289 \\
\hline Observations & 110 & 110 & 110 & 106 & 108 & 108 \\
\hline
\end{tabular}

Note: The regression was estimated by OLS with year and country fixed effects. * Indicates significance level of $10 \%, * *$ indicates significance level of $5 \%$. $* * *$ Indicates significance level of $1 \%$. Clustered standard errors are in the parentheses. WB government effectiveness is referring to the years 2014, 2009, 2005 and 1996. All explanatory variables are computed for the years 2012, 2007, 2003 and 1991 where Government Expenditures represents a decade average (or the longest time periods available for countries with missing data). 
Table 3: Budget institutions and government effectiveness - execution stage

\begin{tabular}{|c|c|c|c|c|}
\hline & \multicolumn{4}{|c|}{ The dependent variable: WB government effectiveness } \\
\hline & (1) & (2) & (3) & (4) \\
\hline Budget Centralization & $-0.027 * *$ & $-0.027 * *$ & $-0.027 * *$ & $-0.026 * *$ \\
\hline At the execution stage & $(0.012)$ & $(0.010)$ & $(0.011)$ & $(0.011)$ \\
\hline Log GDP per-capita & & $\begin{array}{l}\mathbf{0 . 4 9 2 *} \\
(0.252)\end{array}$ & $\begin{array}{c}0.489 \\
(0.304)\end{array}$ & $\begin{array}{c}1.040 * * * \\
(0.379)\end{array}$ \\
\hline Democracy & & & $\begin{array}{c}0.003 \\
(0.111)\end{array}$ & $\begin{array}{l}-0.105 \\
(0.098)\end{array}$ \\
\hline Government expenditures & & & & $\begin{array}{c}-0.000 \\
(0.001)\end{array}$ \\
\hline Adj.R ${ }^{2}$ & 0.228 & 0.288 & 0.280 & 0.373 \\
\hline Observations & 95 & 95 & 95 & 91 \\
\hline
\end{tabular}

See Notes to Table 2. 
Table 4: Budget institutions and government effectiveness - formulation stage

\begin{tabular}{|c|c|c|c|c|}
\hline & \multicolumn{4}{|c|}{ The dependent variable: WB government effectiveness } \\
\hline & (1) & (2) & (3) & (4) \\
\hline Budget Centralization & -0.008 & -0.010 & -0.009 & -0.007 \\
\hline At the Formulation stage & $(0.012)$ & $(0.012)$ & $(0.011)$ & $(0.012)$ \\
\hline Log GDP per-capita & & $\begin{array}{l}\mathbf{0 . 4 3 2} * \\
(0.252)\end{array}$ & $\begin{array}{c}0.390 \\
(0.272)\end{array}$ & $\begin{array}{c}\mathbf{0 . 8 8 6} * * \\
(0.410)\end{array}$ \\
\hline Democracy & & & $\begin{array}{c}0.059 \\
(0.098)\end{array}$ & $\begin{array}{c}-0.007 \\
(0.107)\end{array}$ \\
\hline Government expenditures & & & & $\begin{array}{c}0.001 \\
(0.001) \\
\end{array}$ \\
\hline Adj.R ${ }^{2}$ & 0.203 & 0.236 & 0.233 & 0.275 \\
\hline Observations & 106 & 106 & 106 & 102 \\
\hline
\end{tabular}

See Notes to Table 2. 
Table 5: Budget institutions and government effectiveness - legislation stage

\begin{tabular}{|c|c|c|c|c|}
\hline & \multicolumn{4}{|c|}{ The dependent variable: WB government effectiveness } \\
\hline & (1) & (2) & (3) & (4) \\
\hline Budget Centralization & -0.018 & -0.019 & -0.019 & -0.013 \\
\hline At the Legislation stage & $(0.012)$ & $(0.012)$ & $(0.012)$ & $(0.012)$ \\
\hline Log GDP per-capita & & $\begin{array}{c}0.336 \\
(0.206)\end{array}$ & $\begin{array}{c}0.312 \\
(0.211)\end{array}$ & $\begin{array}{c}0.873 \\
(0.546)\end{array}$ \\
\hline Democracy & & & $\begin{array}{c}0.040 \\
(0.094)\end{array}$ & $\begin{array}{c}-0.022 \\
(0.117)\end{array}$ \\
\hline Government expenditures & & & & $\begin{array}{c}0.002 \\
(0.001) \\
\end{array}$ \\
\hline Adj.R ${ }^{2}$ & 0.189 & 0.203 & 0.197 & 0.231 \\
\hline Observations & 97 & 97 & 97 & 93 \\
\hline
\end{tabular}


Table 6: Budget institutions and government effectiveness

\begin{tabular}{|c|c|c|c|c|}
\hline & \multicolumn{4}{|c|}{ The dependent variable: WB government effectiveness } \\
\hline & (1) & (2) & (3) & (4) \\
\hline $\begin{array}{l}\text { Budget Centralization } \\
\text { At the Execution stage }\end{array}$ & $\begin{array}{c}-0.040 * * * \\
(0.012)\end{array}$ & $\begin{array}{c}-0.040 * * * \\
(0.013)\end{array}$ & $\begin{array}{c}-0.040 * * * \\
(0.012)\end{array}$ & $\begin{array}{l}-0.051 * * * \\
(0.016)\end{array}$ \\
\hline $\begin{array}{l}\text { Budget Centralization } \\
\text { At the Formulation stage }\end{array}$ & $\begin{array}{c}0.018 \\
(0.014)\end{array}$ & $\begin{array}{c}0.018 \\
(0.014)\end{array}$ & $\begin{array}{c}0.020 \\
(0.016)\end{array}$ & $\begin{array}{c}0.001 \\
(0.019)\end{array}$ \\
\hline $\begin{array}{l}\text { Budget Centralization } \\
\text { At the Legislation stage }\end{array}$ & $\begin{array}{c}-0.030 * * \\
(0.012)\end{array}$ & $\begin{array}{c}-0.030 * * \\
(0.014)\end{array}$ & $\begin{array}{c}-0.030 * * \\
(0.014)\end{array}$ & $\begin{array}{l}-0.005 \\
(0.016)\end{array}$ \\
\hline Log GDP per-capita & & $\begin{array}{c}0.050 \\
(0.338)\end{array}$ & $\begin{array}{l}-0.005 \\
(0.989)\end{array}$ & $\begin{array}{c}0.634 \\
(0.532)\end{array}$ \\
\hline Democracy & & & $\begin{array}{l}0.0581 \\
(0.695)\end{array}$ & $\begin{array}{l}-0.206 \\
(0.183)\end{array}$ \\
\hline Government expenditures & & & & $\begin{array}{l}-0.016 \\
(0.006)\end{array}$ \\
\hline $\begin{array}{l}\text { Adj. } \mathrm{R}^{2} \\
\text { Observations }\end{array}$ & $\begin{array}{c}0.291 \\
81\end{array}$ & $\begin{array}{c}0.281 \\
81\end{array}$ & $\begin{array}{c}0.275 \\
81\end{array}$ & $\begin{array}{c}0.363 \\
79\end{array}$ \\
\hline
\end{tabular}

See Notes to Table 2. 
Table 7: Budget institutions and government effectiveness in certain public activities

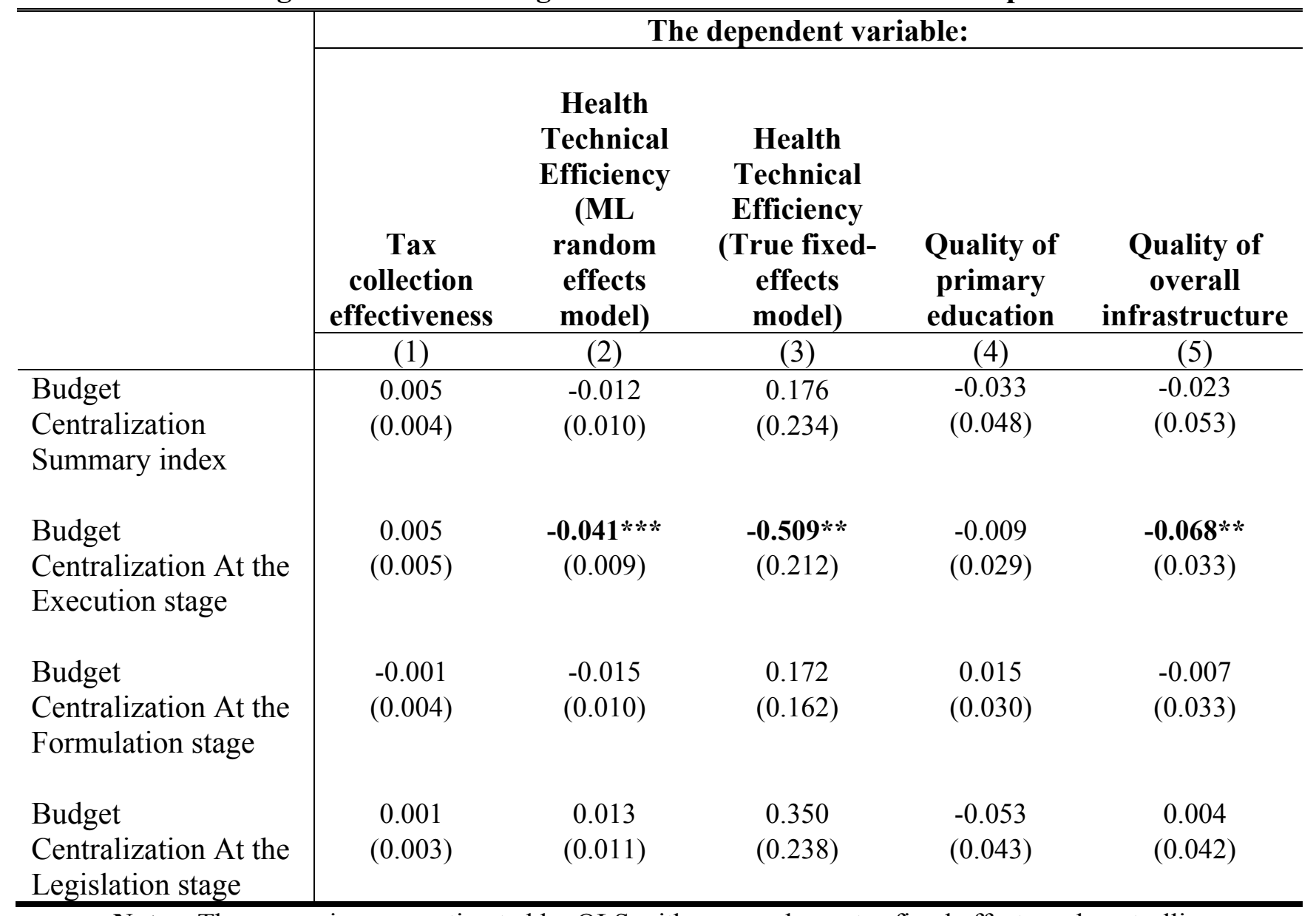

Notes: The regression was estimated by OLS with year and country fixed effects and controlling for Log GDP per-capita and Democracy index. * Indicates significance level of $10 \%$, ** indicates significance level of 5\%. $* * *$ Indicates significance level of $1 \%$. Clustered standard errors are in the parentheses. The table displays the Budget Centralization coefficients. Health Technical Efficiency variables in Columns 2 and 3 were multiplied by 100 in order to obtain informative coefficients. Health Technical Efficiency Dependent variables are referring to the years 2014, 2009, 2005 and 1996 or the nearest available year (see note for table 1) while all explanatory variables are computed for the years 2012,2007, 2003 and 1991. 
Table 8: Budget institutions and government effectiveness - Sensitivity Analysis

\begin{tabular}{|c|c|c|c|c|c|c|}
\hline & \multicolumn{6}{|c|}{ The dependent variable: WB government effectiveness } \\
\hline & $(1)$ & $(2)$ & $(3)$ & $(4)$ & $(5)$ & $(6)$ \\
\hline & & & & & & \\
\hline & & & & & $\begin{array}{l}\text { Above } \\
\text { median }\end{array}$ & $\begin{array}{l}\text { Below } \\
\text { median }\end{array}$ \\
\hline $\begin{array}{l}\text { Budget Centralization } \\
\text { Summary index }\end{array}$ & $\begin{array}{c}-\mathbf{- 0 . 0 3 5}{ }^{\text {**** }} \\
(0.011)\end{array}$ & $\begin{array}{c}-\mathbf{0 . 0 5 7 * * * *} \\
(0.015)\end{array}$ & $\begin{array}{c}\mathbf{- 0 . 0 3 6 * *}^{* *} \\
(0.014)\end{array}$ & $\begin{array}{c}-\mathbf{0 . 0 3 8 * *} \\
(0.015)\end{array}$ & $\begin{array}{l}-0.050 \\
(0.032)\end{array}$ & $\begin{array}{c}-\mathbf{0 . 0 4 6 * * * *} \\
(0.015)\end{array}$ \\
\hline Log GDP per-capita & $\begin{array}{c}0.090 \\
(0.269)\end{array}$ & $\begin{array}{l}\mathbf{0 . 6 3 2 *} \\
(0.357)\end{array}$ & $\begin{array}{c}\mathbf{0 . 6 2 0} * * \\
(0.280)\end{array}$ & $\begin{array}{c}\mathbf{0 . 7 2 0} * * \\
(0.313)\end{array}$ & $\begin{array}{c}-0.833 \\
(1.308)\end{array}$ & $\begin{array}{l}.0695 * * \\
(0.275)\end{array}$ \\
\hline Democracy & $\begin{array}{l}0.013 \\
(0.051)\end{array}$ & $\begin{array}{l}-0.093 \\
(0.129)\end{array}$ & $\begin{array}{l}-0.034 \\
(0.076)\end{array}$ & $\begin{array}{l}-0.055 \\
(0.087)\end{array}$ & omitted & $\begin{array}{c}-0.36 \\
(\mathbf{0 . 0 7 7 )}\end{array}$ \\
\hline Government expenditures & $\begin{array}{c}-\mathbf{- 0 . 0 1 8}^{* * * *} \\
(0.006)\end{array}$ & $\begin{array}{c}-\mathbf{0 . 0 1 5} * * * \\
(0.0057)\end{array}$ & $\begin{array}{l}-\mathbf{- 0 . 0 0 9 *} \\
(0.005)\end{array}$ & $\begin{array}{l}-\mathbf{0 . 0 0 8 *} \\
(0.005)\end{array}$ & $\begin{array}{c}-0.041 * * \\
(0.015)\end{array}$ & $\begin{array}{l}-.005 \\
(\mathbf{0 . 0 0 5 )}\end{array}$ \\
\hline Fiscal Rules & $\begin{array}{l}\mathbf{0 . 0 1 7} * * \\
(0.007)\end{array}$ & & & & & \\
\hline Political Decentralization & & $\begin{array}{c}.025 * * * \\
(0.007)\end{array}$ & & & & \\
\hline Election Year & & & $\begin{array}{l}0.002 \\
(.034)\end{array}$ & & & \\
\hline Log Population Size & & & & $\begin{array}{c}-1.061^{*} \\
(.685) \\
\end{array}$ & & \\
\hline Adj. $R^{2}$ & 0.242 & 0.385 & 0.282 & 0.313 & 0.445 & 0.331 \\
\hline Observations & 97 & 91 & 107 & 108 & 36 & 72 \\
\hline
\end{tabular}

Note: The regression was estimated by OLS with year and country fixed effects. $*$ Indicates significance level of $10 \%, * *$ indicates significance level of $5 \% . * * *$ Indicates significance level of $1 \%$. Clustered standard errors are in the parentheses. WB government effectiveness is referring to the years 2014, 2009, 2005 and 1996. All explanatory variables are computed for the years 2012, 2007, 2003 and 1991 where Government Expenditure represents a decade average (or the longest time periods available for countries with missing data).

In column (1) budget centralization is computed without the fiscal rules component to allow for clean interpretation of its estimated coefficient given that Fiscal Rules Index is included in the list of explanatory variables. 
Table 9: Budget institutions and government effectiveness - reverse causality

\begin{tabular}{l|ccc}
\hline \hline & \multicolumn{3}{|c}{$\begin{array}{c}\text { The dependent variable: } \Delta \text { Budget Centralization } \\
\text { Summary index (2007-2012) }\end{array}$} \\
\cline { 2 - 4 } & $(1)$ & $(2)$ & $(3)$ \\
\hline WB government & 0.151 & -0.483 & -0.545 \\
effectiveness, 2006 & $(0.346)$ & $(0.454)$ & $(0.456)$ \\
Log GDP per-capita 2006 & & 1.236 & 1.179 \\
& & $(0.781)$ & $(0.785)$ \\
Democracy 2006 & & & 0.208 \\
& & & $(0.460)$ \\
Constant & & & -13.127 \\
& -0.438 & -12.381 & $(7.957)$ \\
\hline Adj.R ${ }^{2}$ & $(0.508)$ & $(7.615)$ & 0.012 \\
Observations & -0.025 & 0.039 & 33 \\
\hline Notes: The regres
\end{tabular}

Notes: The regression was estimated by OLS with year and country fixed effects. * Indicates significance level of $10 \%, * *$ indicates significance level of $5 \%$. *** Indicates significance level of $1 \%$. Standard errors of the coefficients are in parentheses. 
Figure 1: Budget Centralization and government effectiveness

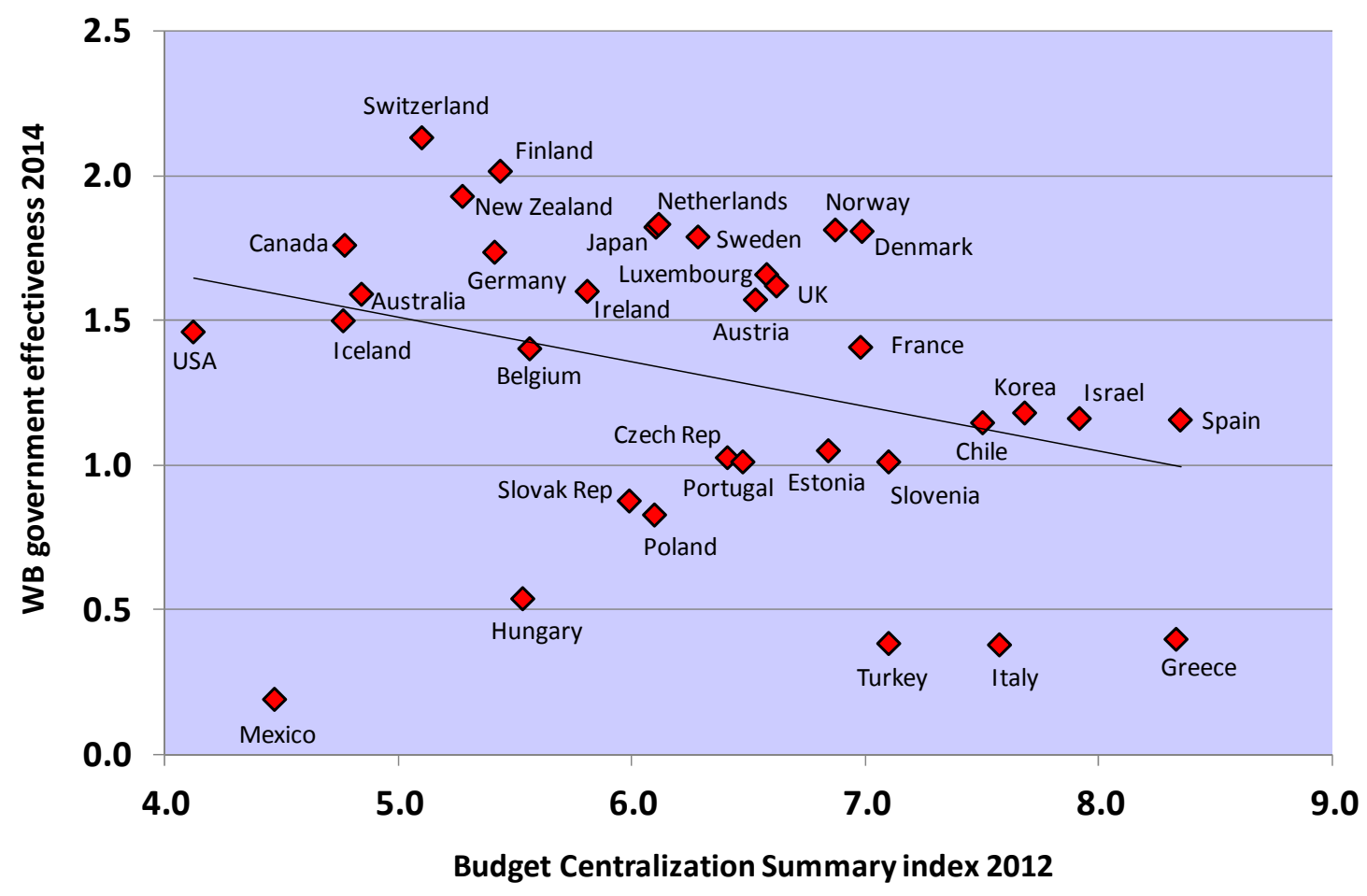


Appendix Table 1: The indices of budget centralization

\begin{tabular}{|c|c|c|c|c|c|c|c|c|c|c|c|c|c|c|c|c|}
\hline & \multicolumn{4}{|c|}{ Formulation Stage } & \multicolumn{4}{|c|}{ Legislation Stage } & \multicolumn{4}{|c|}{ Execution Stage } & \multicolumn{4}{|c|}{ Summary Index } \\
\hline & $\bar{\sigma}$ & હ̊̊ & $\hat{\stackrel{\nu}{~}}$ & 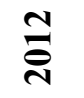 & $\bar{\sigma}$ & ๕ి & હ) & 곡 & $\bar{\sigma}$ & 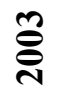 & 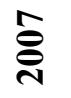 & $\stackrel{\widetilde{O}}{\stackrel{\sim}{\sim}}$ & $\bar{\sigma}$ & ్ֻ̊ㅅ & હิ & 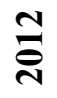 \\
\hline Australia & . & 2.7 & 2.5 & 5.0 & . & 7.5 & & 4.8 & & 2.8 & 4.9 & 4.7 & 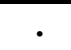 & 4.3 & 3.7 & 4.8 \\
\hline Austria & 2.5 & 2.7 & 6.3 & 7.5 & 2 & 5.7 & 6.2 & 5.6 & 7.4 & 7.6 & 9.1 & . & 3.8 & 5.3 & 7.2 & 6.5 \\
\hline Belgium & 0.6 & 2.7 & 4.4 & 5.0 & 2 & 5.0 & 4.5 & 5.1 & 4.4 & 5.9 & 8.8 & 6.6 & 2.3 & 4.5 & 5.9 & 5.6 \\
\hline Canada & . & 2.2 & 7.5 & 3.1 & . & 6.5 & . & 4.5 & . & 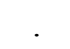 & 4.1 & 6.7 & . & 4.4 & 5.8 & 4.8 \\
\hline Chile & . & . & 8.1 & 8.8 & . & . & . & 6.6 & . & & . & 7.2 & - & . & 8.1 & 7.5 \\
\hline Czech R. & . & 0.7 & 8.1 & 7.5 & . & 4.7 & 4.6 & 7.3 & . & 6.8 & 6.0 & 4.4 & . & 4.0 & 6.2 & 6.4 \\
\hline Denmark & 7.7 & 3.2 & 8.1 & 9.4 & 6 & 4.7 & 5.6 & . & 4.1 & 2.5 & 5.8 & 4.6 & 5.9 & 3.5 & 6.5 & 7.0 \\
\hline Estonia & 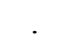 & & & 7.5 & . & & & 5.5 & & & 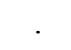 & 7.5 & $\cdot$ & . & . & 6.8 \\
\hline Finland & 3.1 & 4.7 & 8.1 & 8.1 & 3 & 4.7 & 6.1 & 4.3 & 5 & & 6.6 & 3.9 & 3.7 & 4.7 & 6.9 & 5.4 \\
\hline France & 10 & 4.2 & 6.9 & 7.5 & 9 & & 6.7 & 6.5 & 8.2 & $\cdot$ & . & . & 9 & 4.2 & 6.8 & 7.0 \\
\hline Germany & 7.5 & 4.7 & 6.3 & 6.9 & 2 & 5.3 & 5.7 & 4.8 & 7.6 & 4.9 & 6.3 & 4.6 & 5.8 & $\mathbf{5 . 0}$ & 6.1 & 5.4 \\
\hline Greece & 0.6 & . & 6.3 & 10.0 & 0 & 8.3 & 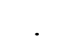 & 7.4 & 6 & 8.1 & 9.2 & 7.6 & 2.3 & 8.2 & 7.7 & 8.3 \\
\hline Hungary & . & 4.7 & 7.5 & 4.4 & . & 3.7 & 5.0 & . & . & 6.7 & 6.5 & 6.7 & . & $\mathbf{5 . 0}$ & 6.3 & 5.5 \\
\hline Iceland & . & 6.2 & 8.1 & 4.4 & . & 6.7 & 5.2 & 4.2 & 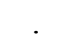 & 3.6 & 6.1 & 5.7 & . & 5.5 & 6.5 & 4.8 \\
\hline Ireland & 1.9 & . & 7.5 & 5.6 & 4 & 9.4 & 7.7 & 6.0 & 4.3 & 7.0 & 6.1 & . & 3.5 & 8.2 & 7.1 & 5.8 \\
\hline Israel & . & 8.0 & 8.8 & 8.8 & . & 8.1 & 7.3 & 8.0 & . & 7.2 & 7.5 & 7.0 & . & 7.7 & 7.9 & 7.9 \\
\hline Italy & 4.8 & 6.2 & 9.4 & 8.8 & 3 & 6.0 & 5.0 & . & 0.4 & 6.9 & 7.5 & 6.4 & 2.7 & 6.4 & 7.3 & 7.6 \\
\hline Japan & . & 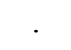 & 7.5 & 8.1 & . & 7.8 & 7.2 & 4.5 & . & & 9.1 & 5.7 & . & 7.8 & 7.9 & 6.1 \\
\hline Korea & . & 4.2 & 4.4 & 8.1 & . & 7.1 & 5.2 & 7.9 & . & 5.3 & 7.3 & 7.0 & . & 5.5 & 5.6 & 7.7 \\
\hline Luxembourg & 6.9 & & 8.1 & 7.5 & 4 & & 5.8 & 5.4 & 5 & & 7.5 & 6.8 & 5.3 & . & 7.2 & 6.6 \\
\hline Mexico & . & 6.2 & 10.0 & 6.3 & . & 5.9 & 4.1 & 2.7 & . & 7.5 & 6.3 & . & . & 6.5 & 6.8 & 4.5 \\
\hline Netherlands & 6.7 & 4.7 & 8.1 & 8.1 & 8 & 2.7 & 3.6 & 5.3 & 2.1 & 6.8 & 5.9 & 4.9 & 5.6 & 4.7 & 5.9 & 6.1 \\
\hline New Zealand & . & 4.5 & 5.0 & 5.6 & . & 7.8 & 6.2 & 4.5 & . & 6.6 & 8.7 & 5.7 & . & 6.3 & 6.6 & 5.3 \\
\hline Norway & . & 2.7 & 3.8 & 6.3 & . & 3.3 & 4.4 & . & . & & 6.1 & 7.5 & . & 3.0 & 4.7 & 6.9 \\
\hline Poland & . & & 8.8 & 7.5 & . & & 6.6 & . & . & & 6.1 & 4.7 & . & . & 7.2 & 6.1 \\
\hline Portugal & 6 & 5.2 & 8.8 & 7.5 & 2.5 & 5.0 & 6.6 & 5.8 & 5.8 & 6.9 & 6.3 & 6.1 & 4.9 & 5.7 & 7.2 & 6.5 \\
\hline Slovak R. & . & 2.7 & 7.5 & 7.5 & . & 6.4 & 5.6 & 5.4 & . & 6.8 & 6.2 & 5.1 & . & 5.3 & 6.4 & 6.0 \\
\hline Slovenia & . & . & 9.4 & 9.4 & . & . & 7.3 & 5.9 & . & . & 6.3 & 6.0 & - & . & 7.7 & 7.1 \\
\hline Spain & 3.8 & . & 6.3 & 9.4 & 2 & 6.4 & 7.3 & 7.3 & 2.4 & 7.5 & . & . & 2.7 & 7.0 & 6.8 & 8.4 \\
\hline Sweden & 3.3 & 6.2 & 6.9 & 7.5 & 6 & 4.3 & 5.2 & 5.2 & 2.2 & & 4.8 & 6.2 & 3.2 & 5.3 & 5.6 & 6.3 \\
\hline Switzerland & . & . & 6.3 & 6.3 & . & 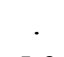 & 4.6 & 4.2 & - & $\cdot$ & 4.5 & 4.9 & . & $\cdot$ & 5.1 & 5.1 \\
\hline Turkey & . & 4.2 & 7.5 & 7.5 & . & 5.9 & 5.4 & . & . & 7.0 & 9.2 & 6.7 & . & 5.7 & 7.4 & 7.1 \\
\hline UK & 9.4 & 6.2 & 6.3 & 8.8 & 8 & . & 6.5 & 4.5 & 4.6 & 5.0 & 7.7 & . & 7.4 & 5.6 & 6.8 & 6.6 \\
\hline United States & . & 1.7 & 2.5 & 3.8 & . & 2.7 & 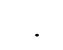 & 3.0 & . & 7.2 & 4.7 & 5.6 & - & 3.9 & 3.6 & 4.1 \\
\hline
\end{tabular}

Source: The constructed indices of budget centralization are based on OECD, Budgeting Practices and Procedures in OECD Countries.

Note: The index of budget centralization at each particular stage of the budgetary process is constructed only if a country answered all the questions. The summary index is a simple average of the indices at the three stages (or less). 


\begin{tabular}{|c|c|c|c|c|c|c|c|c|}
\hline \multicolumn{9}{|c|}{ Appendix Table 2: Contrstruction of a budget centralization index in the formulation stage } \\
\hline \multicolumn{3}{|c|}{2003} & \multicolumn{3}{|l|}{2007} & \multicolumn{3}{|l|}{2012} \\
\hline \multicolumn{3}{|c|}{$\begin{array}{l}\text { 2.1.a.1 : In developing the budget, are there fiscal rules placing } \\
\text { limits on Executive fiscal policy discretion? }\end{array}$} & \multicolumn{3}{|c|}{$\begin{array}{c}\text { Q.14: In developing the budget, are there any fiscal rules that place limits } \\
\text { on fiscal policy? }\end{array}$} & \multicolumn{3}{|c|}{ 18. : Does the government have in place any fiscal rules that place limits on fiscal policy? } \\
\hline $\begin{array}{c}\text { Reply } \\
\text { yes }\end{array}$ & $\underset{1}{\text { ranking }}$ & $\begin{array}{l}\text { Standardized } \\
10\end{array}$ & Reply & $\underset{0}{\text { ranking }}$ & $\begin{array}{c}\text { Standardized } \\
0=0\end{array}$ & Reply & $\begin{array}{c}\text { ranking } \\
0\end{array}$ & $\begin{array}{c}\text { Standardized } \\
0=0\end{array}$ \\
\hline no & 0 & 0 & Yes, expenditure rule & 1 cumulative & $1=2.5$ & expenditure rule & 1 cumulative & $1=2.5$ \\
\hline \multicolumn{3}{|c|}{$\begin{array}{l}\text { 2.1.a.4 : Is your country subject to any fiscal rules by a supra- } \\
\text { national organisation? (e.g Maastricht treaty) }\end{array}$} & Yes, revenue rule & 1 cumulative & $2=5$ & revenue rule & 1 cumulative & $2=5$ \\
\hline Reply & ranking & Standardized & Yes, budget balance (surplus/deficit) rule & 1 cumulative & $3=7.5$ & budget balance & 1 cumulative & $3=7.5$ \\
\hline Yes, please specify & 1 & 10 & Yes, debt rule & 1 cumulative & $4=10$ & debt & 1 cumulative & $4=10$ \\
\hline No & 0 & 0 & Other & 1 cumulative & & & & \\
\hline \multicolumn{3}{|c|}{$\begin{array}{l}\text { 2.4.e : Who has the last word? How are disputes between } \\
\text { Ministries and the central budget authority resolved? }\end{array}$} & \multicolumn{3}{|c|}{$\begin{array}{c}\text { Q.26: In practice how are disputes between line ministries and the Central } \\
\text { Budget Authority in the budget preparation process generally resolved i.e. } \\
\text { issues not resolved at civil servant level? }\end{array}$} & \multicolumn{3}{|c|}{$\begin{array}{l}\text { 33. : During the budget negotiation process, who has the final/ultimate decision making power to } \\
\text { resolve/settle disputes? }\end{array}$} \\
\hline \multirow{6}{*}{$\begin{array}{l}\text { The issue is sent to parliament } \\
\text { for decision } \\
\text { The minister of finance makes } \\
\text { all final decisions } \\
\text { The issues are resolved by the } \\
\text { President/Prime } \\
\text { Minister/Principal Executive } \\
\text { Cabinet } \\
\text { The issues are sent to a } \\
\text { ministerial committee } \\
\text { Other, please specify }\end{array}$} & ranking & Standardized & Reply & ranking & Standardized & \multirow[b]{2}{*}{ a. President (33_A) } & ranking & Standardized \\
\hline & 0 & 0 & The issue is resolved by the Minister of Finance & 3 & 10 & & 3 & 10 \\
\hline & 3 & 10 & The issue is resolved by the Prime Minister & 3 & 10 & b. Prime Minister (33_B) & 3 & 10 \\
\hline & 3 & 10 & The issue is resolved by the President & 3 & 10 & c. Minister of Finance $\left(33 \_\right.$C) & 3 & 10 \\
\hline & 1 & 2.5 & The issue is resolved by the Cabinet & 1 & 2.5 & \multirow{2}{*}{$\begin{array}{l}\text { d. Cabinet (33_D) } \\
\text { e. Ministerial committee (33_E) } \\
\text { f. Other, please explain: (33_F) }\end{array}$} & 1 & 2.5 \\
\hline & 2 & 5 & The issue is sent to a ministerial committee & 2 & 5 & & 2 & 5 \\
\hline \multicolumn{3}{|c|}{$\begin{array}{l}\text { 2.4.d : Are there established rules or procedures to guide central } \\
\text { budget authority negotiations with line ministries? }\end{array}$} & \multicolumn{3}{|c|}{$\begin{array}{l}\text { Q.23 : Does the Central Budget Authority impose limits (ceilings) for each } \\
\text { ministry's initial spending request? }\end{array}$} & \multicolumn{3}{|c|}{$\begin{array}{l}\text { 31. : Does the government impose budget ceilings on the initial spending requests of each line } \\
\text { ministry? }\end{array}$} \\
\hline Reply & ranking & Standardized & Reply & ranking & Standardized & \multirow{9}{*}{$\begin{array}{l}\text { Reply } \\
\text { a. Yes for total/overall expenditure of the line ministry (31_A) } \\
\text { b. Yes for other aggregate levels (e.g by program or sector) (31_B) } \\
\text { c. Yes for agency level or other organisational level (31_C) } \\
\text { d. No, there are no such limits (31_D) }\end{array}$} & ranking & Standardized \\
\hline yes & 1 & 0 & \multirow{8}{*}{$\begin{array}{l}\text { No, there are no such limits } \\
\text { No, there are only suggested/indicative limits } \\
\text { Yes, but only for some types of expenditure (e.g. } \\
\text { salaries) on a chapter level } \\
\text { Yes, but only for some types of expenditure (e.g. } \\
\text { Yes, for all types of expenditure at a chapter } \\
\text { level } \\
\text { Yes, for all types of expenditure at a line item }\end{array}$} & 0 & $0=0$ & & 1 & $0=0$ \\
\hline no & 0 & 10 & & 0 & $1=10$ & & 1 & $1=10$ \\
\hline \multirow{2}{*}{\multicolumn{3}{|c|}{$\begin{array}{l}\text { 2.4.f : What percentage of the initial executive branch budget is } \\
\text { decided by the President/Prime Minister/Principal Executive (i.e. } \\
\text { Reply } \quad \text { ranking Standardized }\end{array}$}} & & 1 & & & 1 & \\
\hline & & & & 1 & & & 0 & \\
\hline 0 to $15 \%$ & 1 & 1 & & 1 & & & & \\
\hline 16 to $30 \%$ & 2 & & & 1 & & & & \\
\hline 31 to $50 \%$ & 3 & & & 1 & & & & \\
\hline More than $50 \%$ & 4 & 10 & & & & & & \\
\hline & & & Q.1: Where is the function of the Central B & udget Authori & ity located? & 1a. : Where is the function of the Central Budget Authority (CB & ted in your go & overnment? \\
\hline & & & Reply & ranking & Standardized & Reply & ranking & Standardized \\
\hline & & & Ministry of Finance/Economy & 1 & $\begin{array}{ll}1=10 \\
0=0\end{array}$ & Where: Ministry of Finance/Economy & 1 & $1=10$ \\
\hline & & & & 0 & $0=0$ & Where: otherwise & 0 & $0=0$ \\
\hline
\end{tabular}




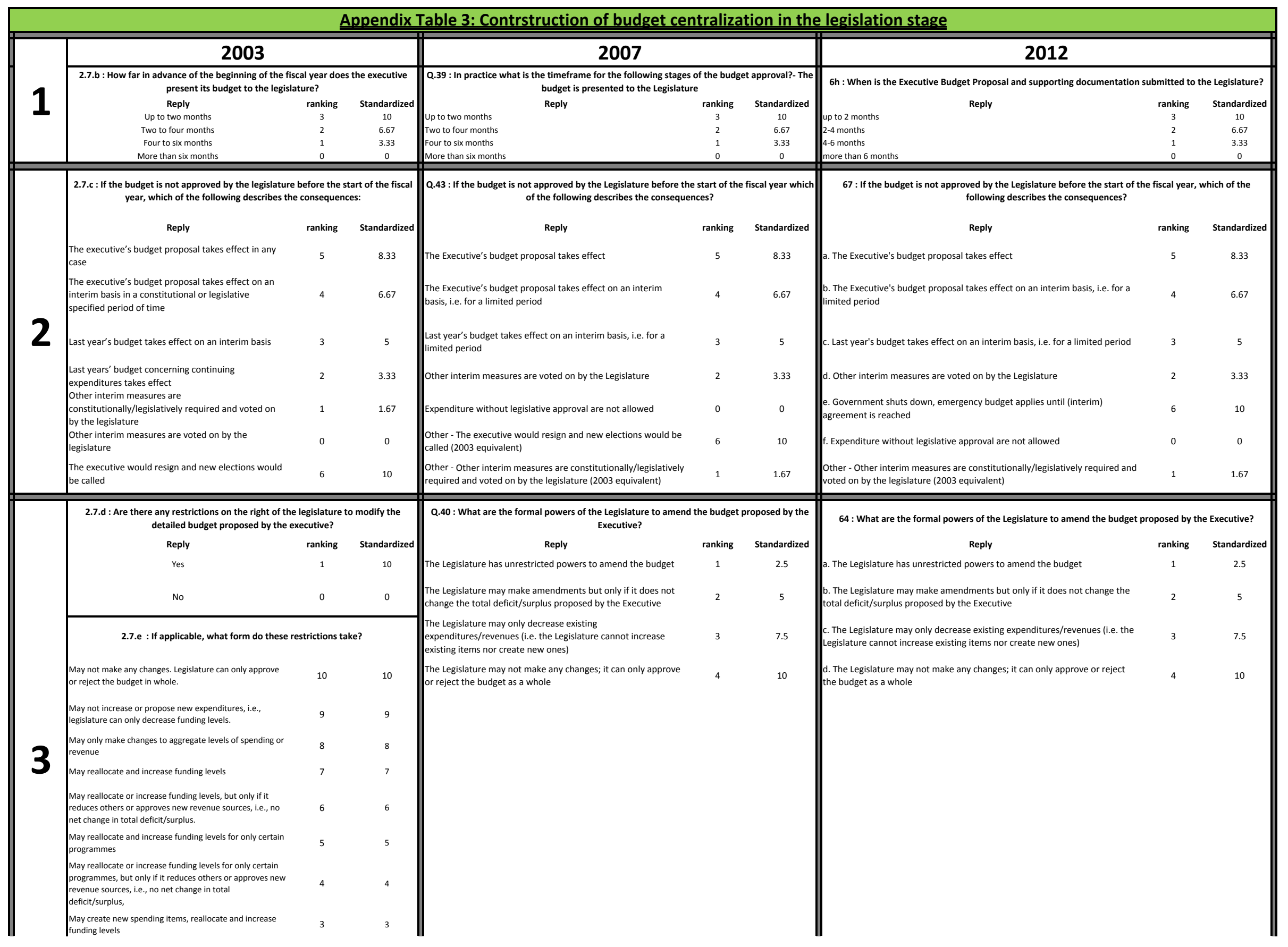




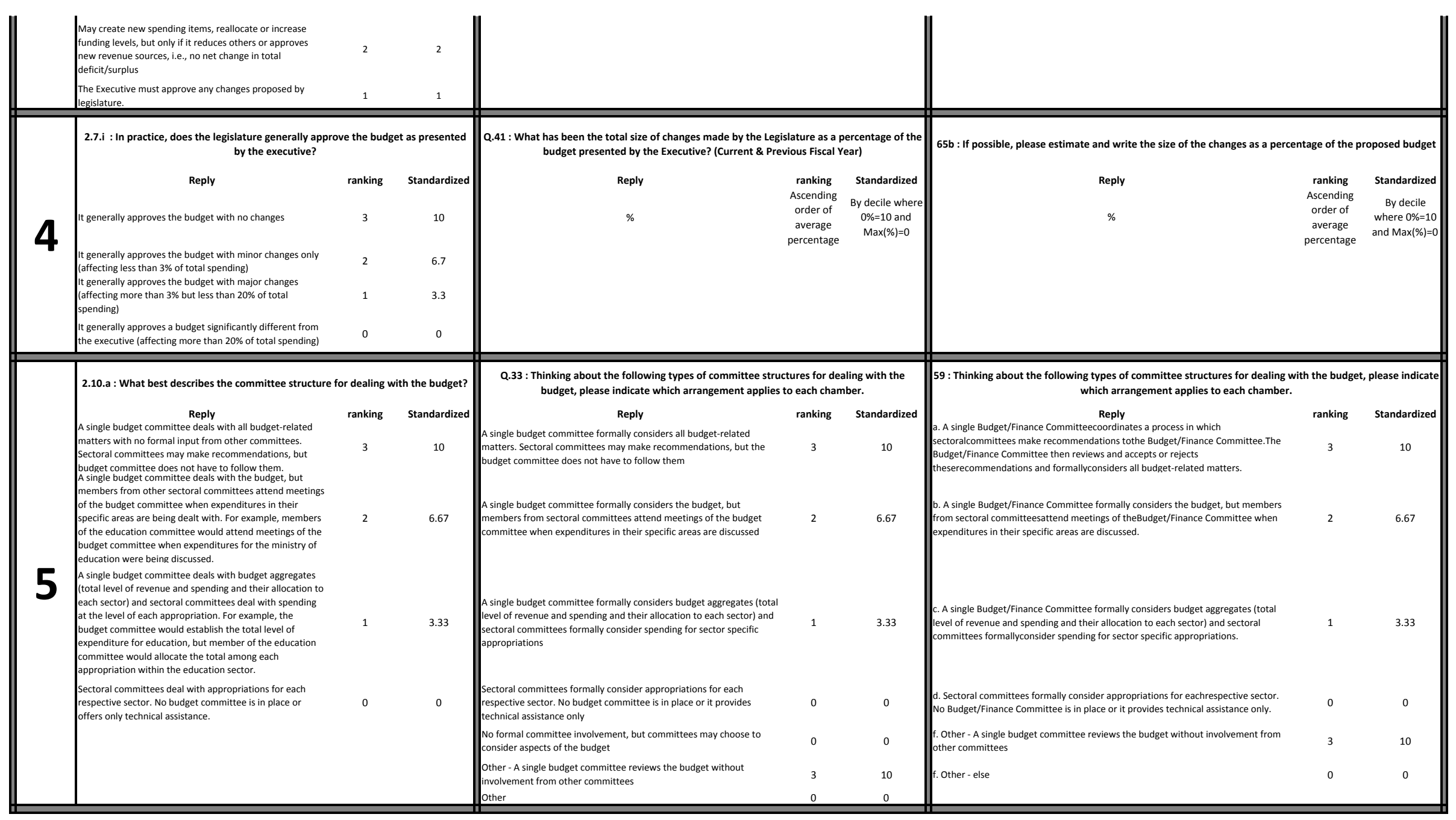




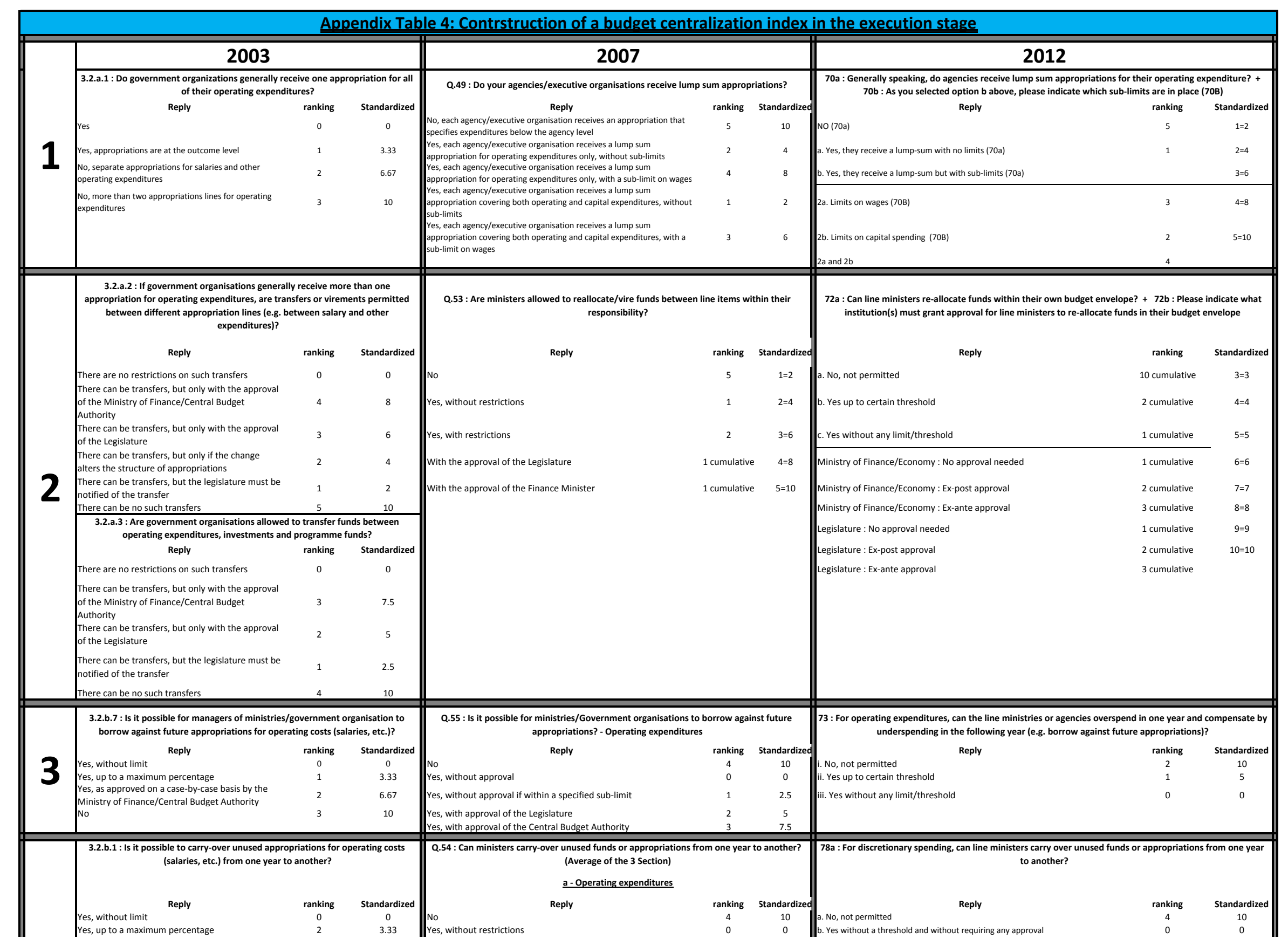




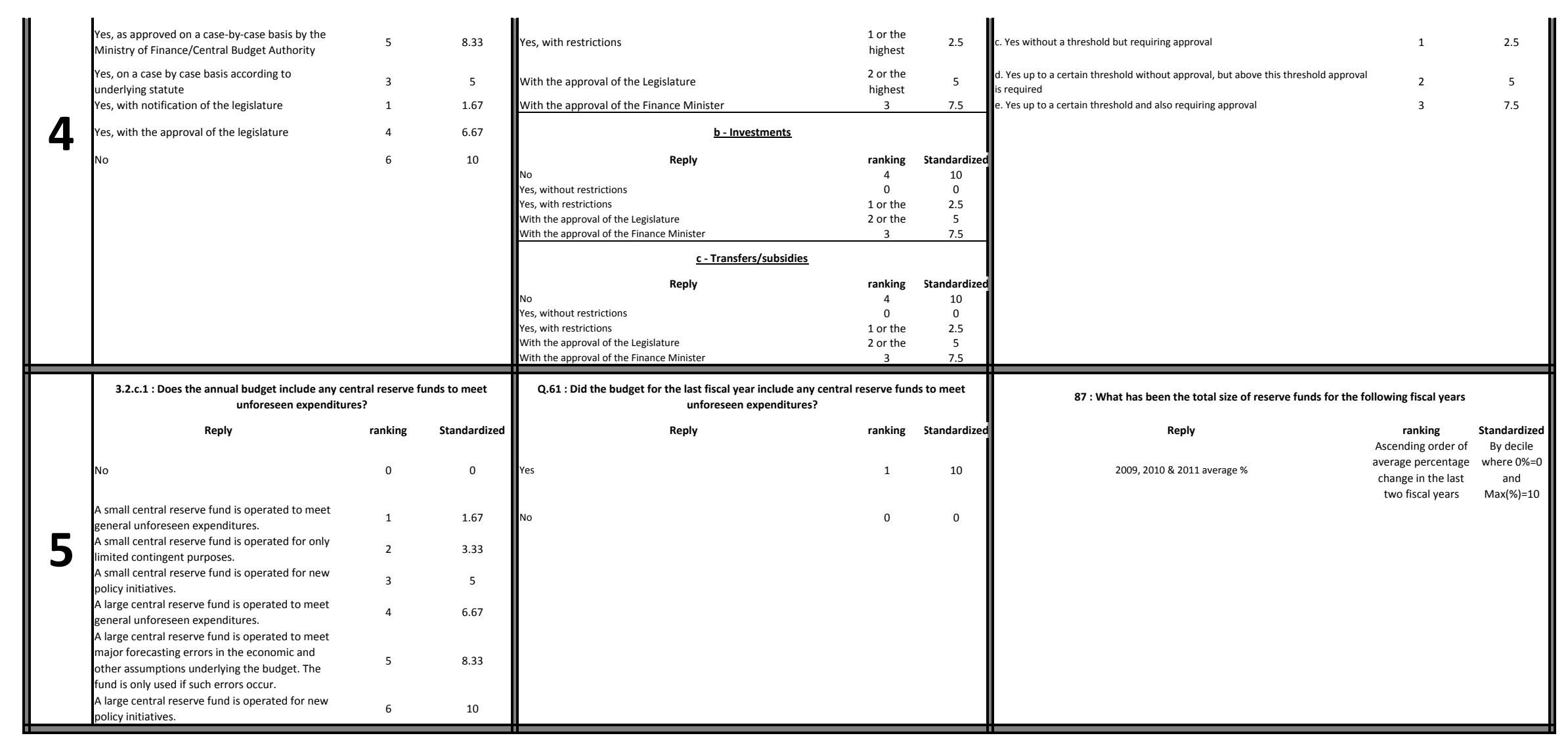

